In cooperation with U.S. Fish and Wildlife Service

Changes in Streamflow Patterns Related to Hydrologic Restoration of a Sedge Fen Wetland in Seney National Wildlife Refuge, Michigan, 1998-2004

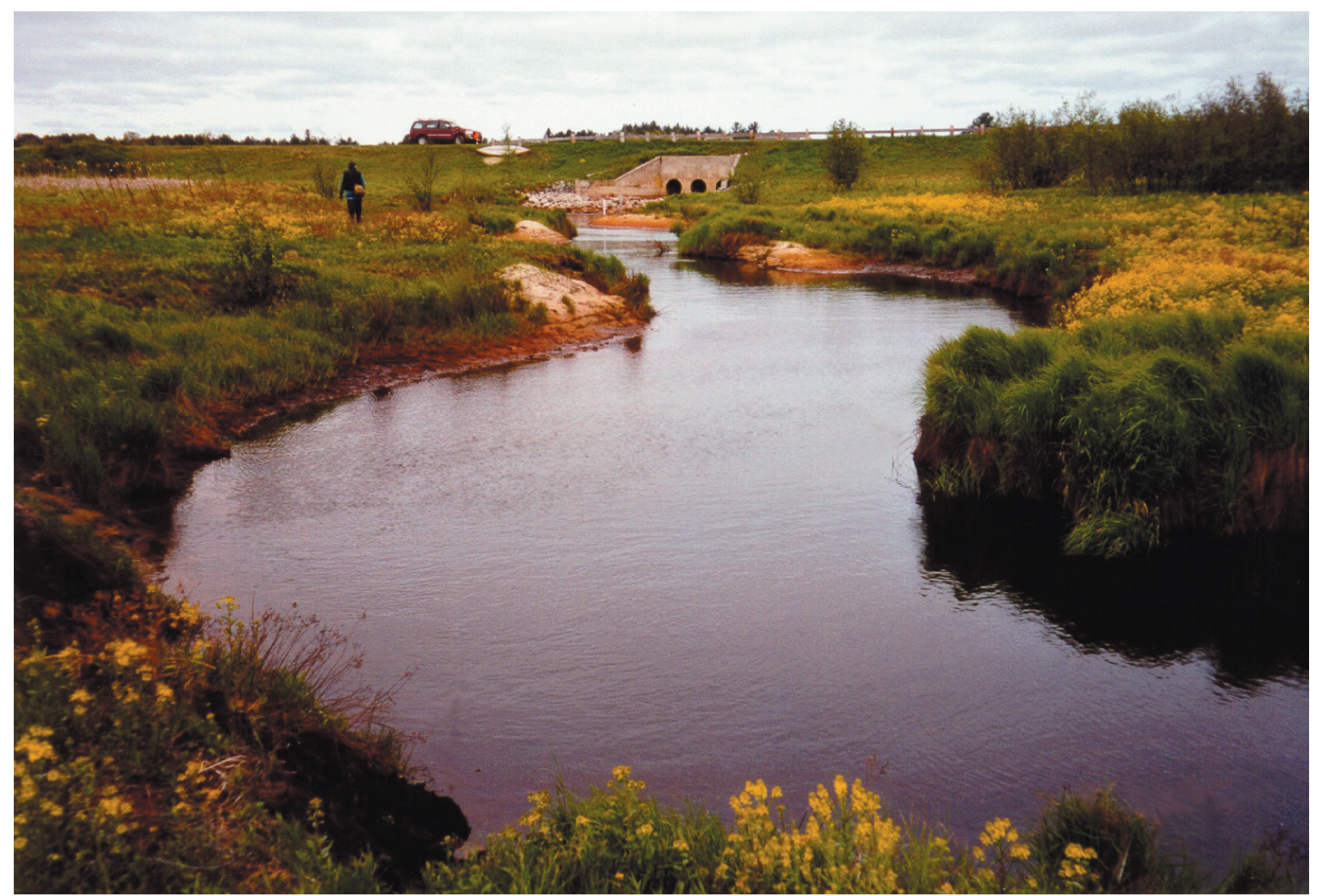

Scientific Investigations Report 2005-5137 
Cover Photograph. Sweeney Creek at Seney National Wildlife Refuge, Michigan. Photograph by D.G. Wydra. 


\section{Changes in Streamflow Patterns Related to Hydrologic Restoration of a Sedge Fen Wetland in Seney National Wildlife Refuge, Michigan, 1998-2004}

By B.P. Neff, T.L. Weaver, and D.G. Wydra

In Cooperation with U.S. Fish and Wildlife Service

Scientific Investigations Report 2005-5137 


\section{U.S. Department of the Interior \\ Gale A. Norton, Secretary}

\section{U.S. Geological Survey \\ P. Patrick Leahy, Acting Director}

\section{U.S. Geological Survey, Reston, Virginia 2005}

For sale by U.S. Geological Survey, Information Service

Box 25286, Denver Federal Center

Denver, CO 80225

For more information about the USGS and its products:

Telephone: 1-888-ASK-USGS

World Wide Web: http://www.usgs.gov/

Any use of trade, product, or firm names in this publication is for descriptive purposes only and does not imply endorsement by the U.S. Government.

Although this report is in the public domain, permission must be secured from the individual copyright owners to reproduce any copyrighted material contained within this report.

Suggested citation:

Neff, B.P., Weaver, T.L., and Wydra, D.G., 2005, Changes in Streamflow Patterns Related to Hydrologic Restoration of a Sedge Fen Wetland in Seney National Wildlife Refuge, Michigan, 1998-2004: U.S. Geological Survey Scientific Investigations Report 2005-5137, 20 p. 


\section{Contents}

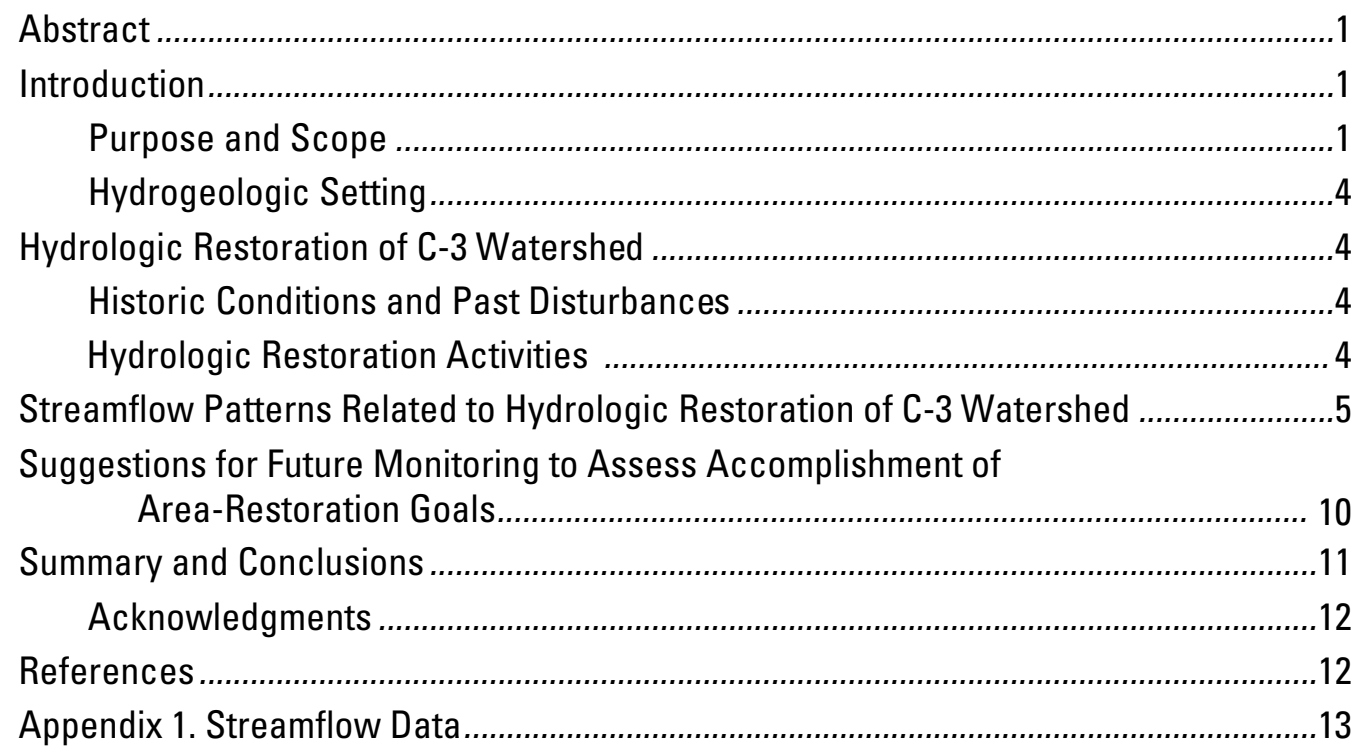

\section{Figures}

1-2. Maps showing Seney National Wildlife Refuge study area, Michigan:

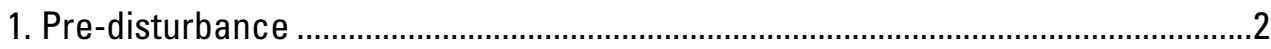

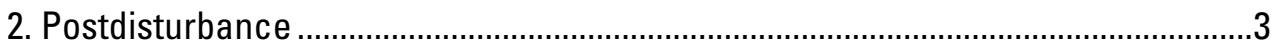

3-4. Schematic diagrams showing hydrologic flow in and near Seney National Wildlife Refuge study area, Michigan:

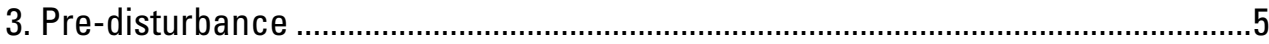

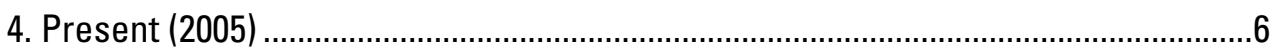

5. Map showing dams, control structures, and intended routing of surface water in Seney National Wildlife Refuge study area, Michigan ............................................................................................................

6. Bar chart showing flows in Seney National Wildlife Refuge study area,

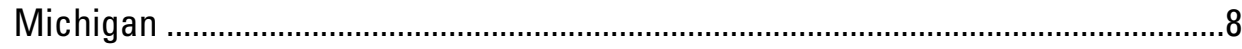

\section{Tables}

1. Flows in Walsh Ditch and tributaries, Seney National Wildlife Refuge study area, Michigan

2. Flows in Driggs River and tributaries, Seney National Wildlife Refuge study area, Michigan ..... 


\section{Conversion Factors}

\begin{tabular}{|c|c|c|}
\hline Multiply & By & To obtain \\
\hline \multicolumn{3}{|c|}{ Length } \\
\hline foot $(\mathrm{ft})$ & 0.3048 & meter (m) \\
\hline inch (in.) & 25.4 & millimeter (mm) \\
\hline mile (mi) & 1.609 & kilometer (km) \\
\hline foot per mile (ft/mi) & 0.1894 & meter per kilometer $(\mathbf{m} / \mathbf{k m})$ \\
\hline \multicolumn{3}{|c|}{ Area } \\
\hline square mile $\left(\mathbf{m i}^{2}\right)$ & 2.590 & square kilometer $\left(\mathbf{k m}^{2}\right)$ \\
\hline \multicolumn{3}{|l|}{ Flow rate } \\
\hline cubic foot per second $\left(\mathrm{ft}^{3} / \mathrm{s}\right)$ & 0.02832 & cubic meter per second $\left(\mathrm{m}^{3} / \mathrm{s}\right)$ \\
\hline
\end{tabular}

Temperature in degrees Celsius $\left({ }^{\circ} \mathrm{C}\right)$ may be converted to degrees Fahrenheit $\left({ }^{\circ} \mathrm{F}\right)$ as follows:

${ }^{\circ} \mathrm{F}=\left(1.8 \mathrm{x}^{\circ} \mathrm{C}\right)+32$ 


\title{
Changes in Streamflow Patterns Related to Hydrologic Restoration of a Sedge Fen Wetland in Seney National Wildlife Refuge, Michigan, 1998-2004
}

\author{
By B.P. Neff, T.L. Weaver, and D.G. Wydra
}

\begin{abstract}
Vast expanses of sedge fen in Schoolcraft County in Michigan's Upper Peninsula were ditched and diked in the early to mid-1900s to promote agricultural development and create waterfowl habitat. Unintended consequences of these actions were far reaching and included the deposition of large amounts of sand in the Manistique River. In 2002, the U.S. Fish and Wildlife Service, which now manages much of the wetland as part of Seney National Wildlife Refuge, attempted to restore streamflow to Walsh Creek and overland flow downgradient of Walsh Ditch, near C-3 Pool. Streamflow data were collected before and after remediation activities. These data indicate that efforts to restore flow to Walsh Creek were partially successful, but it is unclear whether overland flow was restored downgradient from Walsh Ditch. Alternatives for future evaluation of restoration of flow to Walsh Creek include monitoring streamflow at three easily accessible locations. Restoration of overland flow downgradient from Walsh Ditch can be assessed in the future by monitoring flows at three additional sites. Restoration of either site can be assessed by monitoring vegetation shifts, possibly with aerial or satellite imagery.
\end{abstract}

\section{Introduction}

Historically, much of the land in and near what is now Seney National Wildlife Refuge (NWR) in Michigan's Upper Peninsula was an expansive ground-water-supported sedge fen (fig. 1). In the 1900s, this land was ditched and diked for agricultural development and, later, for waterfowl management. Major changes included the construction of Walsh Ditch and C-3 Pool (fig. 2). These activities severely disrupted the hydrology, and subsequently the ecology, of the surrounding area. Notably, these actions led to significant erosion, particularly in the portion of Walsh Ditch known as "The Spreads" (fig. 2), which has resulted in deposition of sand into Manistique River and degradation of salmonid spawning habitat (Wilcox and others, in press). Much of the affected area was later incorporated into Seney National Wildlife Refuge and is managed by the U.S. Fish and Wildlife Service (USFWS).

Currently, USFWS is attempting to restore the historical hydrologic regime to part of this affected area in an attempt to revive the once-vast sedge fen and stop erosion in lower Walsh Ditch (fig. 2). Restoration efforts are designed to directly reduce erosion and may indirectly improve wetland habitat.

Previous studies were done in association with the restoration project to guide refuge managers and to provide prerestoration data for use in evaluating ecological and environmental changes during and after restoration activities. These studies evaluated ecological conditions related to presence of Walsh Ditch and C-3 Pool (Kowalski and Wilcox, 2003), assessed hydrologic conditions in the wetland (Sweat, 2001), and described the use of hydrologic data to evaluate potential reallocation of inputs and outputs during high-flow periods to guide restoration of surface- and ground-water hydrology in the affected C-3 Pool/Walsh Ditch area (Wilcox and others, in press).

\section{Purpose and Scope}

This report summarizes previous reports on restoration efforts and presents all streamflow data collected at 20 miscellaneous streamflow measurement sites and 2 streamflow gaging stations (21 locations overall) in the study area from 1998 through 2004. Also, this report describes the current understanding of the effectiveness of hydrologic restoration efforts in the $\mathrm{C}-3$ watershed in the refuge. 


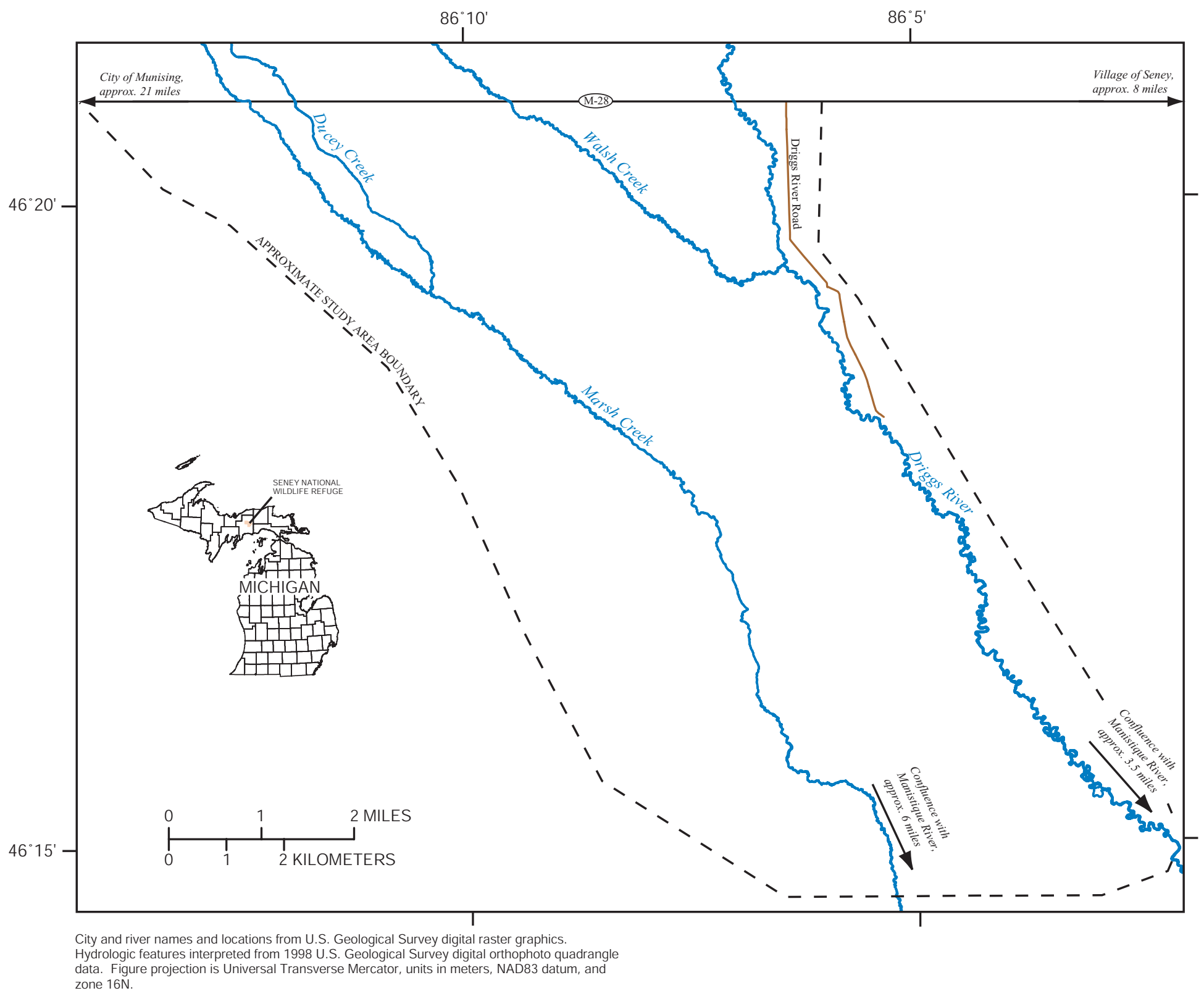

Figure 1. Seney National Wildlife Refuge study area, Michigan, pre-disturbance. 


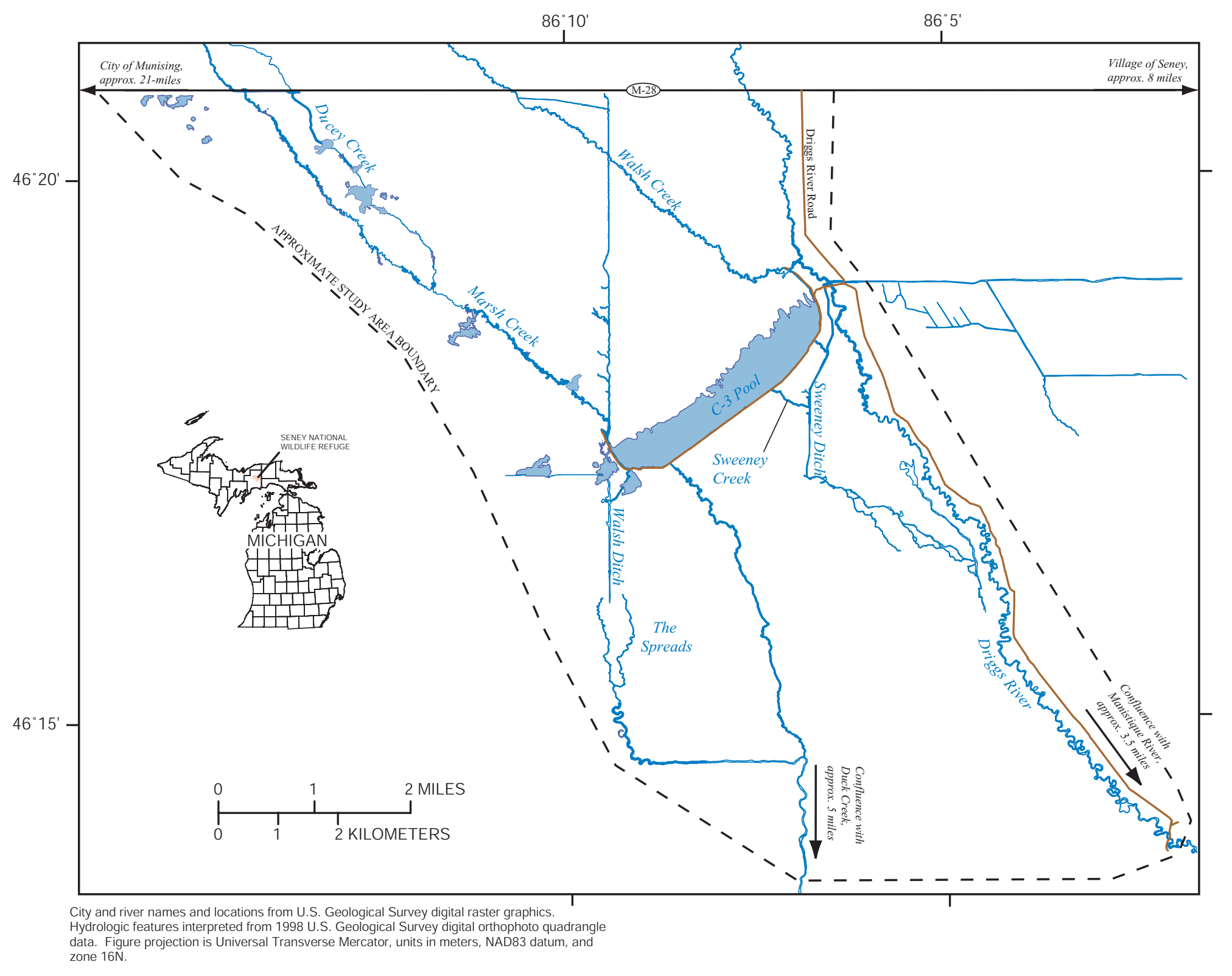

Figure 2. Seney National Wildlife Refuge study area, Michigan, post-disturbance. 


\section{Hydrogeologic Setting}

The study area is in the central Upper Peninsula of Michigan (figs. 1,2). Terrain slopes southeast at approximately $8 \mathrm{ft} / \mathrm{mi}$, as inferred from USGS 7.5-minute topographic quadrangle maps (Driggs Lake Southeast and Walsh quadrangles, 1972). Surficial sediments are primarily of glacial origin and overlie sandstone, limestone, and dolomite (Sweat, 2001). Much of the refuge contains peat deposits ranging in thickness from a few inches to more than $6 \mathrm{ft}$, a characteristic of bogs and fens (Smith, 1992; Niering, 1994; Sweat, 2001). Sweat (2001) and Wilcox and others (in press) describe the area north of C-3 Pool as largely forested, with a mixture of sedge fen and shrubdominated areas. Outcrops of sand provide adequate habitat for islands of upland vegetation. Thirty-year average precipitation and temperature for the study area are 31.65 in. and approximately $5.1{ }^{\circ} \mathrm{C}$ (National Climatic Data Center, 2002).

Kowalski (2000) and Wilcox and others (in press) document that water in the peatland is mineralized and representative of water chemistry of a highly alkaline fen. During low-flow season (winter), surface-water specific conductance typically ranged from 175 to $275 \mu \mathrm{S} / \mathrm{cm}, \mathrm{pH}$ ranges from 6.8 to 7.7 units, and alkalinity ranged from 115 to $150 \mathrm{mg} / \mathrm{L}$ as $\mathrm{CaCO}_{3}$. Ground-water specific conductance generally ranged from 215 to $400 \mu \mathrm{S} / \mathrm{cm}, \mathrm{pH}$ ranges from 6.5 to 7.1 units, and alkalinity ranged from 140 to $180 \mathrm{mg} / \mathrm{L}$ as $\mathrm{CaCO}_{3}$ (Kowalski, 2000).

Damage to the historical sedge-fen wetland resulted directly and indirectly in modifications to the landscape. Directly, sedge-fen habitat has been damaged by the construction of ditches and dikes, as well as from inundation by C-3 Pool. Indirectly, ditches and dikes have altered the ground- and surface-water hydrology of much of the historical sedge fen. This alteration has led to the lowering of the water table in many areas and has contributed to the loss of habitat by wildfire. The degree to which the initial wetland has been affected has not been quantified.

\section{Hydrologic Restoration of C-3 Watershed}

Drainage patterns in the study area are complex and highly altered by past attempts to establish agriculture and wildlife resources. Restoration efforts have attempted to mitigate some of the alterations by redistributing streamflow throughout the study area, particularly to and from C-3 Pool.

\section{Historic Conditions and Past Disturbances}

Historically, surface water flowed through the study area in Marsh Creek, Ducey Creek, Walsh Creek, and the Driggs River (figs. 1, 3). Sheet flow (overland flow) was substantial. The water table was near the land surface and supported a vast sedge fen. Ground water discharged into the peat and streams and flowed under streambeds as hyporheic flow.

In support of agricultural development, the largest wetland drainage project in Michigan's history was begun at and around the study site in 1912 (Wilcox and others, in press). Walsh Ditch was constructed to redirect Walsh and Marsh Creeks and to lower the water table (figs. 2, 4). Despite this effort, agriculture proved unsustainable and was soon abandoned.

Unintended consequences of the wetland drainage project were far reaching. Walsh Ditch was not constructed large enough to handle the large spring streamflow in Walsh and Marsh Creeks and consequently became severely eroded. Large volumes of sand were eroded from Walsh Ditch and discharged into the Manistique River, negatively impacting salmonid spawning habitat (Wilcox and others, in press). Additionally, erosion in Walsh Ditch has incised the landscape sufficiently to lower groundwater levels in parts of the study area, most notably in the area known as "The Spreads" (fig. 2), which has resulted in dehydration, oxidation, and subsidence of wetland peat. Dehydrated peat caught on fire in the 1970s and smoldered to great depths along drainage ditches. Wilcox and others (in press) report that these changes have altered vegetation and wildlife habitat in much of the wetland.

After agricultural development failed, the area was incorporated into Seney National Wildlife Refuge in 1935. C-3 Pool was created in the early 1940s as waterfowl habitat. The pool was constructed by building a dike roughly perpendicular to the flow of water in the study area. Water was diverted to C-3 Pool primarily from Walsh Ditch.

Although this construction successfully created waterfowl habitat, it also diverted water away from Driggs River, curtailed sheet flow across the wetland downstream from C-3 Pool, and raised the water table in the area. Comparison of figures 3 and 4 illustrates the hydrologic complexity of the current wetland.

\section{Hydrologic Restoration Activities}

Hydrologic restoration activities have had two primary goals: to restore streamflow to Walsh Creek and Marsh Creek and to reestablish overland flow downgradient of Walsh Ditch. These goals were accomplished by preventing water from flowing south through Walsh Ditch and by redistributing outflow from C-3 Pool. 
Streamflow in Walsh Creek was restored by damming Walsh Ditch immediately south of the Walsh Creek/Walsh Ditch confluence in late October 2002 (fig. 5). Damming the ditch forced runoff to flow southeast through Walsh Creek and has prevented runoff from flowing south into Walsh Ditch. Concerns were raised regarding reduced channel efficiency of Walsh Creek and potential for backflow from Walsh Creek flooding highway M-28. As a precautionary measure, Walsh Creek was modified from its origin to its confluence with Walsh Ditch to dissipate possible backwater conditions. To date (2005), no flooding problems have been reported. A control structure on Walsh Creek upstream from the Driggs River confluence (fig. 5) allows managers to divert Walsh Creek streamflow to C-3 Pool. To date, water has not been diverted to C-3 Pool, and Walsh Creek has been allowed to flow naturally to Driggs River.

Marsh Creek streamflow has been restored below C-3 Pool by changing the routing of C-3 outflow to Marsh Creek and preventing it from flowing to Walsh Ditch. Outflow from C-3 Pool is distributed between Marsh Creek and Sweeney Ditch by means of control structures at C-3 Pool.

Overland flow has been restored in the study area by damming Walsh Ditch at nine locations downstream from Walsh Creek and upstream from C-3 Pool. This action has created a nearly continuous chain of small ponds in the Walsh Ditch channel, supplied largely by ground water that is intercepted by the ditch channel. In the past, this water flowed south through Walsh Ditch. By preventing flow through Walsh Ditch, water is forced to take one of two routes. First, water may seep back into the ground and flow downgradient to the southeast. Second, water may spill over the downhill (east) side of the ditch channel and flow overland to the southeast across the study area.

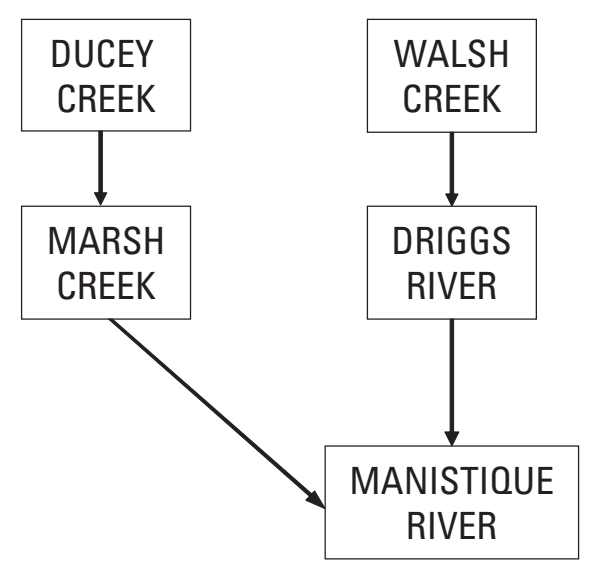

Figure 3. Pre-distrubance hydrology in Seney National Wildlife Refuge study area, Michigan.

\section{Streamflow Patterns Related to Hydrologic Restoration of C-3 Watershed}

Because of the remoteness of the study area and a consequent lack of data due to the difficulty of data collection, a water-balance approach was used to evaluate the effectiveness of hydrologic restoration. The water-balance approach was based on streamflow-measurements at 21 locations in the study area from 1998 to 2004. The effectiveness of remote Walsh Ditch dams can be quantified by monitoring streamflow at more accessible locations. Also, timing and distribution of streamflow downstream of C-3 Pool can be quantified. Results are listed in appendix 1. All streamflow measurements were made and data compiled according to methods described in Rantz and others (1982).

For water years 1999-2000 (WY, Oct. 1, 1998 - Sept. 30, 2000), streamflow through Walsh Ditch between Walsh Creek and C-3 Pool was assessed by use of equation 1:

where

$$
\mathrm{D}_{\mathrm{c}}+\mathrm{M}_{\mathrm{c}}+\mathrm{W}_{\mathrm{c}}=\mathrm{W}_{\mathrm{d}}
$$

$\mathrm{D}$ is Ducey Creek at highway M-28 (04053520), $\mathrm{M}_{\mathrm{c}}$ is Marsh Creek at highway M-28 (04053500), $\mathrm{W}_{\mathrm{c}}$ is Walsh Creek at highway M-28 (04052500), and $\mathrm{W}_{\mathrm{d}}^{\mathrm{c}}$ is Walsh Ditch 0.2 mile upstream from C-3 Pool (04054420)

Equation 1 compares the sum of streamflow through Ducey Creek (measured at USGS miscellaneous streamflow measurement site 04053520), Marsh Creek (04053500), and Walsh Creek (04052500), all measured at highway M-28, to streamflow through Walsh Ditch just upstream from C-3 Pool (04054420). When these streamflows are equal, it indicates that all of the streamflow through Walsh Creek is diverted into Walsh Ditch and flows to C-3 Pool. Slight disagreement in these sums may result from evapotranspiration, changes in water storage, and increases in runoff between points of measurement. This method requires nearconcurrent measurements of all four streamflows. Measurements necessary to make this evaluation were made on 11 days during the study.

Results show that streamflow at Walsh Ditch $0.2 \mathrm{mi}$. upstream of from C-3 Pool was similar to the sum of the streamflow through Marsh Creek, Ducey Creek, and Walsh Creek, each measured where they intersect highway M-28 (fig. 6, table 1). This similarity suggests that most, or all, of Walsh Creek was being diverted into Walsh Ditch at both high and low streamflow on these dates. This observation is consistent with the fact that Walsh Ditch was not dammed until late October 2002. 


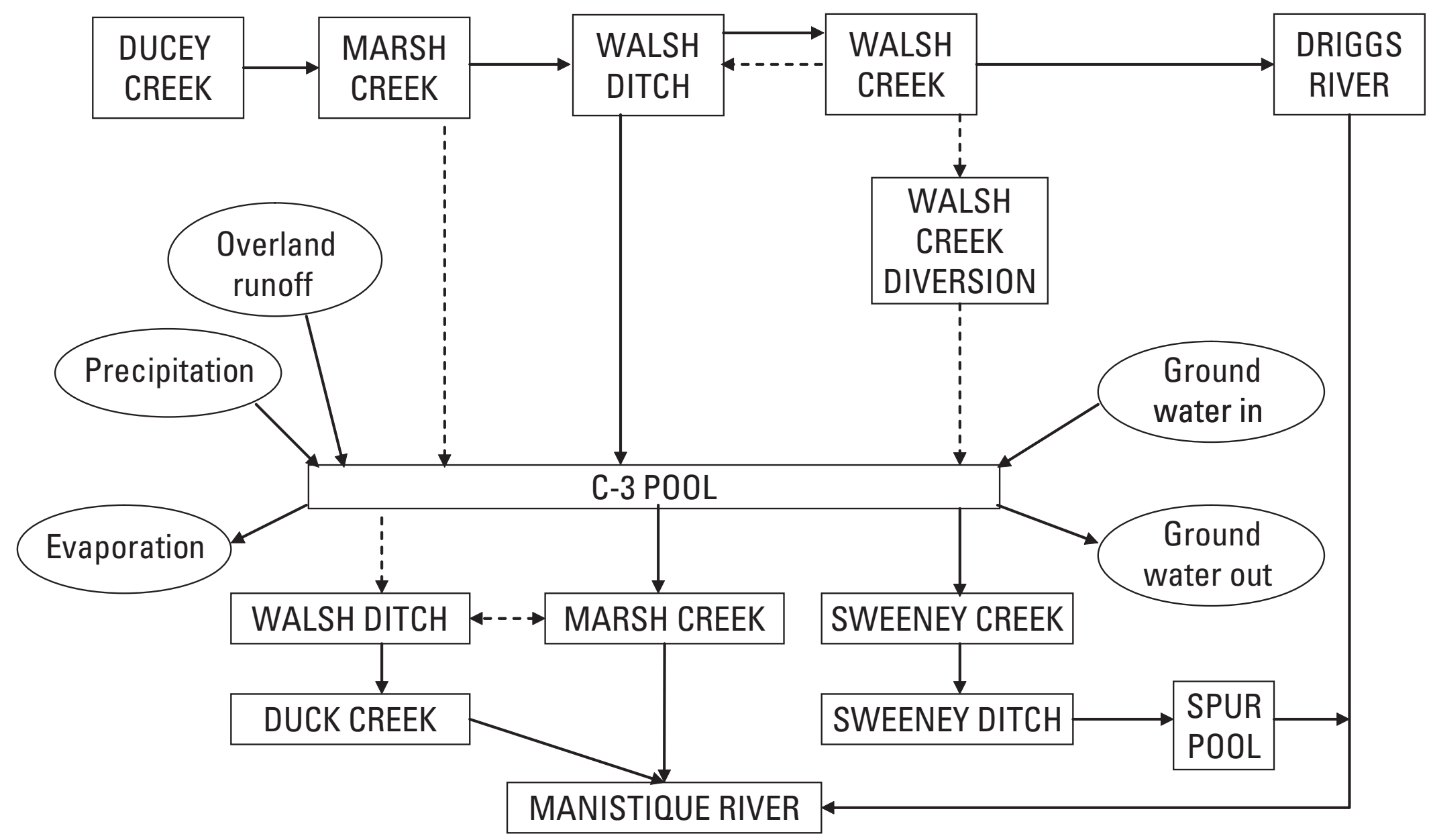

Figure 4. Present (2005) hydrology of Seney Wildlife Refuge study area, Michigan. [Solid lines indicate predominant flows, dashed lines indicate unknown, intermittent, or secondary flows.] 
$86^{\circ} 10^{\prime}$

$86^{\circ} 5^{\prime}$

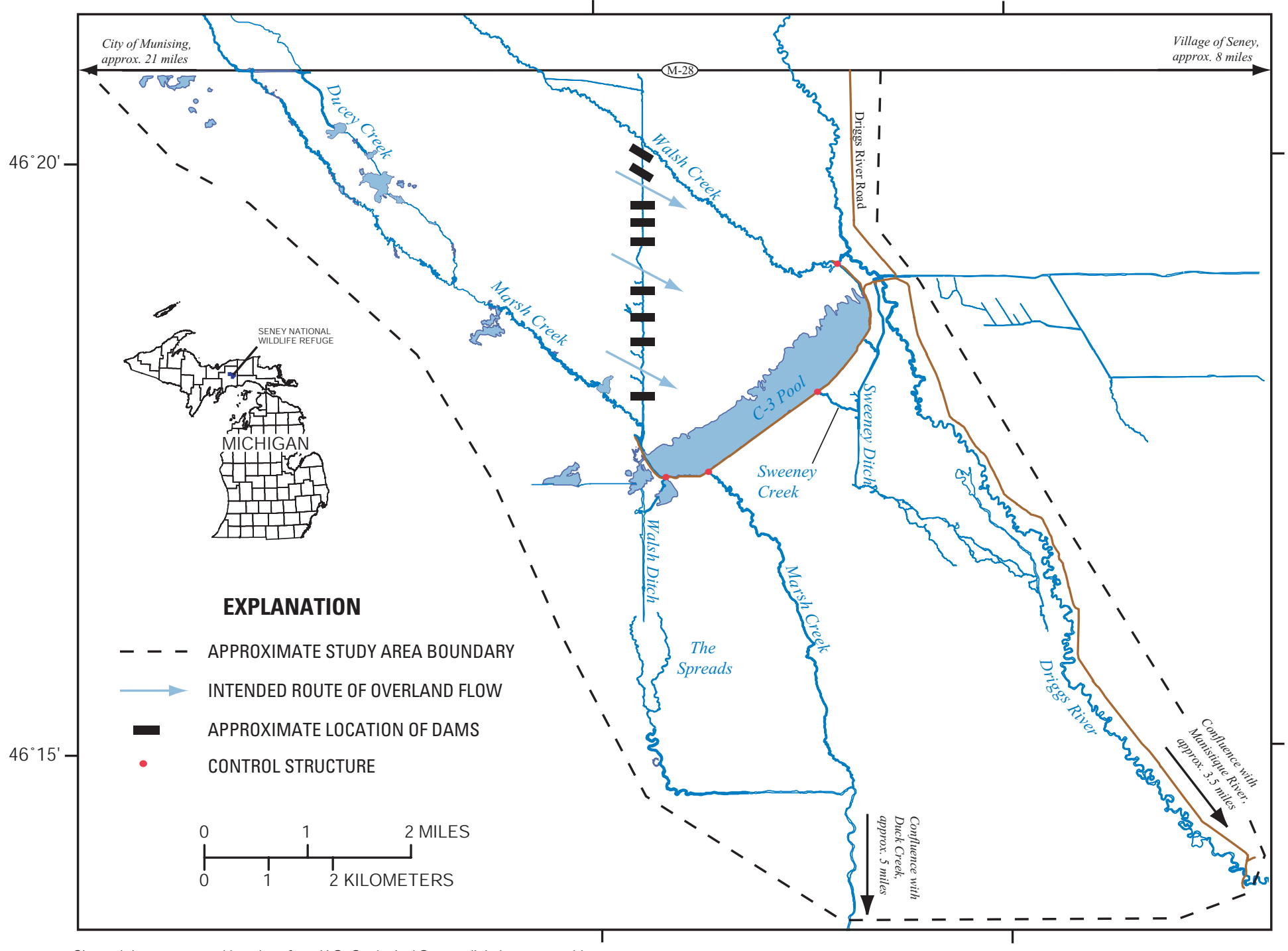

City and river names and locations from U.S. Geological Survey digital raster graphics.

Hydrologic features interpreted from 1998 U.S. Geological Survey digital orthophoto quadrangle zone $16 \mathrm{~N}$.

Figure 5. Dams, control structures, and intended routing of surface water in Seney Wildlife Refuge Study area, Michigan. 

Refuge, Michigan, 1998-2004
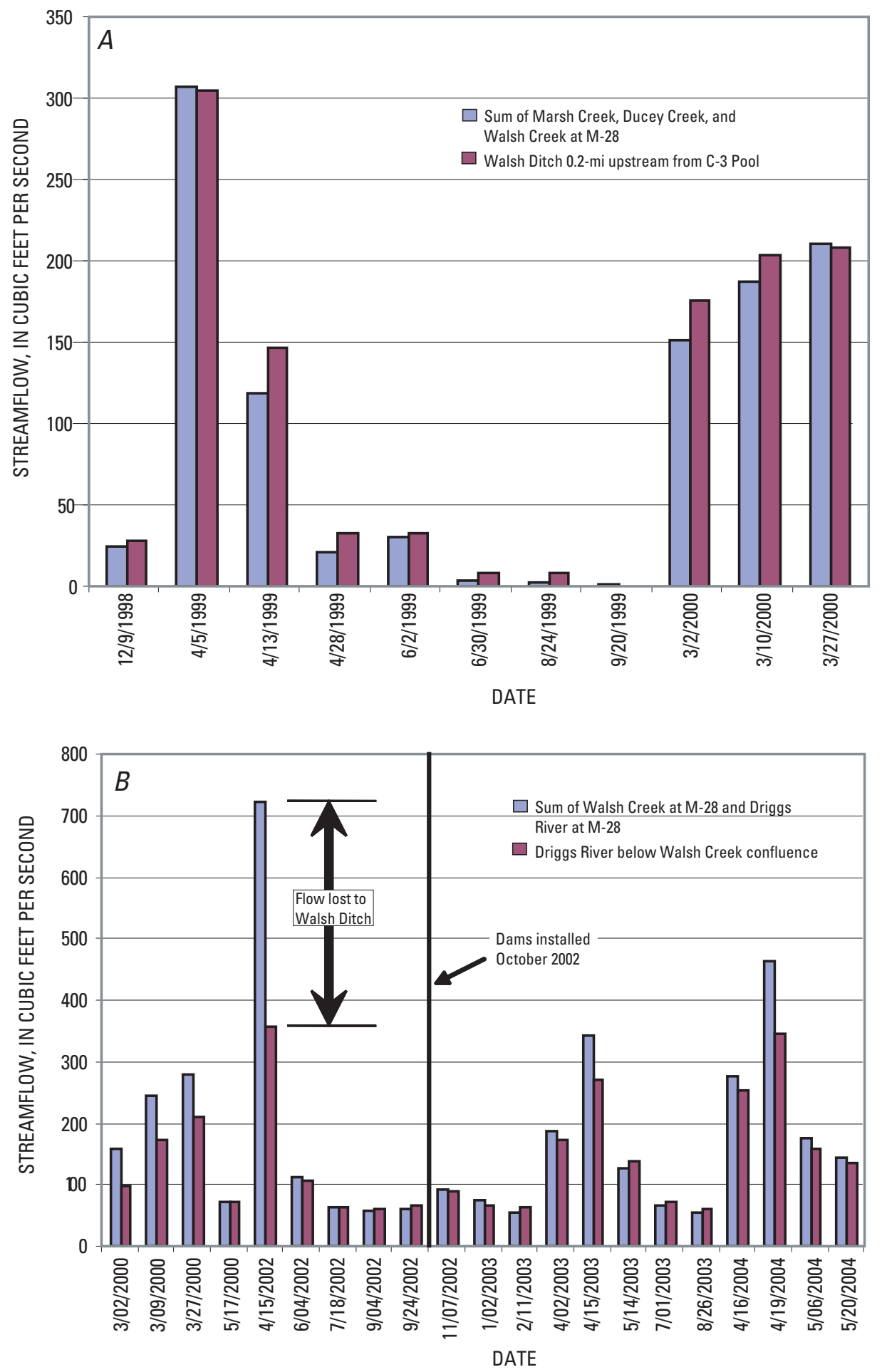

Figure 6. Flows in Seney National Wildlife Refuge study area, Michigan. [A, Walsh Ditch and tributaries, and B, Driggs River and tributaries.] 
Table 1. Flows in Walsh Ditch and tributaries, Seney National Wildlife Refuge study area, Michigan.

[Numbers in parentheses in column headings are USGS station/site numbers. All data in feet per second.]

\begin{tabular}{|c|c|c|c|c|c|c|}
\hline Date & $\begin{array}{c}\text { Walsh Creek at } \\
\text { highway M-28 } \\
\text { (04052500) }\end{array}$ & $\begin{array}{c}\text { Marsh Creek } \\
\text { at highway } \\
\text { M-28 } \\
(04053500)\end{array}$ & $\begin{array}{c}\text { Ducey Creek } \\
\text { at highway } \\
\text { M-28 } \\
\text { (04053520) }\end{array}$ & $\begin{array}{l}\text { Sum of pre- } \\
\text { ceding three } \\
\text { columns }\end{array}$ & $\begin{array}{l}\text { Walsh Ditch } 0.2 \mathrm{mi} \text { up- } \\
\text { stream from C-3 Pool } \\
\text { (04054420) }\end{array}$ & Difference \\
\hline 12/9/1998 & 13.3 & 2.55 & 8.08 & 23.93 & 28.2 & 4.27 \\
\hline 4/5/1999 & 197 & 18.4 & 92.1 & 307.5 & -- & -2.5 \\
\hline 4/6/1999 & -- & -- & -- & -- & 305 & \\
\hline 4/13/1999 & 66 & 11 & 41.4 & 118.4 & 147 & 28.6 \\
\hline 4/28/1999 & 13.4 & 2.72 & 5.38 & 21.5 & -- & 109 \\
\hline 4/29/1999 & -- & -- & -- & -- & 32.4 & \\
\hline 6/2/1999 & 19.2 & 0.85 & 10.3 & 30.35 & -- & 2.15 \\
\hline 6/3/1999 & -- & -- & -- & -- & 32.5 & \\
\hline 6/29/1999 & -- & -- & -- & -- & 8.12 & 5.21 \\
\hline 6/30/1999 & 2.91 & 0 & 0 & 2.91 & -- & \\
\hline 8/24/1999 & 2.18 & 0 & 0 & 2.18 & 7.56 & 5.38 \\
\hline 9/20/1999 & 1.62 & 0 & 0 & 1.62 & 0 & -1.62 \\
\hline $3 / 2 / 2000$ & 80.4 & 12.4 & 57.9 & 150.7 & 176 & 25.3 \\
\hline $3 / 8 / 2000$ & -- & 11.2 & 59.7 & -- & 204 & 88 \\
\hline $3 / 10 / 2000$ & 116 & -- & -- & 116 & -- & \\
\hline $3 / 27 / 2000$ & 123 & 11.9 & 75.8 & 210.7 & 208 & -2.7 \\
\hline
\end{tabular}

For WY 2000-04, streamflow through Walsh Ditch between Walsh Creek and C-3 Pool was determined by use of equation 2. This equation compares the sum of streamflow through Walsh Creek (04052500) and Driggs River (04052000), both measured at highway M-28, to Driggs River streamflow measured a few hundred yards downstream from the Walsh Creek confluence (04052600). When the sum of these streamflows is equal, it indicates that all of the streamflow through Walsh Creek was reaching Driggs River and was not diverted into Walsh Ditch. If the sum of the two upstream flows is greater than the downstream measurement, it indicates loss of water from either Walsh Creek or Driggs River. Because it is extremely unlikely that water is ever lost from Driggs River, this scenario suggests that water was lost from Walsh Creek between highway M-28 and the Driggs River confluence. Slight disagreement in these sums may have resulted from evapotranspiration, changes in water storage, and increases in runoff between points of measurement. This method required concurrent measurements of all three streamflows. Measurements necessary to make this evaluation were made on 21 days during 2000-04.

where

$$
\mathrm{W}_{\mathrm{c}}+\mathrm{D}_{\mathrm{M}-28}=\mathrm{D}_{\mathrm{d}}
$$

$\mathrm{W}_{\mathrm{c}}$ is Walsh Creek at highway M-28 (04052500), $\mathrm{D}_{\mathrm{M}-28}^{\mathrm{c}}$ is Driggs River at highway M-28(04052000), and $\mathrm{D}_{\mathrm{d}}$ is Driggs River downstream from the Walsh Creek confluence (04052600) 


\section{Changes in Streamflow Patterns Related to Hydrologic Restoration of a Sedge Fen Wetland in Seney National Wildlife Refuge, Michigan, 1998-2004}

Before installation of dams on Walsh Ditch in October 2002, results showed that the sum of streamflow in Walsh Creek and Driggs River at highway M-28 was greater than Driggs River streamflow below the confluence of the two rivers whenever Walsh Creek streamflow exceeded $80 \mathrm{ft}^{3} / \mathrm{s}$ (table 1). This is especially evident on April 15, 2002, when Walsh Creek at highway M-28 was flowing at $332 \mathrm{ft}^{3} / \mathrm{s}$ (the highest rate of the study period). When streamflow on Walsh Creek at highway M-28 was less than $15 \mathrm{ft}^{3} / \mathrm{s}$ this pattern was not observed. The overall pattern suggests that water was being lost from Walsh Creek between highway M-28 and the Driggs River confluence when Walsh Creek flows increased to somewhere between 15 and $80 \mathrm{ft}^{3} / \mathrm{s}$.

After installation of dams on Walsh Ditch, a similar - but perhaps muted - pattern was observed. Water was evidently lost from Walsh Creek whenever streamflow exceeded $152 \mathrm{ft}^{3} / \mathrm{s}$; however, losses appear to be curtailed when streamflow on Walsh Creek is less than $83 \mathrm{ft}^{3} / \mathrm{s}$. This result suggests water was being lost from Walsh Creek between highway M-28 and the Driggs River confluence when Walsh Creek flows increased to somewhere between 83 and $152 \mathrm{ft}^{3} / \mathrm{s}$.

The loss of water in Walsh Creek channel between highway M-28 and the confluence with the Driggs River following installation of dams on Walsh Ditch in October 2002 was likely due to one or more of three factors. First, water may have been bypassing the dam installed in 2002 on Walsh Ditch and flowing south through the ditch. This possibility is consistent with ongoing erosion damage to Walsh Ditch dams and could account for all of the lost streamflow. Second, Walsh Creek may have been overflowing its banks and flooding the surrounding landscape. The steep gradient of the study area likely prevents standing water from persisting; however, if overland flow traveled south from Walsh Creek to C-3 Pool, it would be diverted to Sweeney Creek and Marsh Creek. Springtime levels in C-3 Pool are somewhat higher than expected based on levels and flows in other parts of the refuge (Tracy Casselman, U.S. Fish and Wildlife Service, written commun., 2005). No data are available to confirm or refute the existence of overland flow from Walsh Creek to C-3 Pool. Third, Walsh Creek may overflow its banks during high flows, allowing water to infiltrate the peat substrate.

A mass balance approach was taken to evaluate if the loss of water from Walsh Creek following installation of dams on Walsh Ditch in October 2002 could be explained by water overflowing the banks and infiltrating the surrounding peatland. The total amount of water loss and the maximum possible amount of water that could infiltrate the surrounding peatland were estimated and compared. The amount of water lost from Walsh Creek after installation of the dams is estimated to be sufficient to cover the surrounding $4 \mathrm{mi}^{2}$ area to a depth of approximately $4 \mathrm{ft}$. This amount is based on an estimate that the amount of streamflow lost from Walsh Creek averages $100 \mathrm{ft}^{3} / \mathrm{s}$ for a 2 week duration and as much as $4 \mathrm{mi}^{2}$ could be affected if water overflowed the banks of Walsh Creek. Shallow, undecomposed peat is known to have specific yields (Sy) of between 0.1 and 0.8 (Boelter, 1965; Boelter and Verry, 1977; Ingram, 1983). In other words, an increase in the water table of $5 \mathrm{ft}$ over $4 \mathrm{mi}^{2}$ could explain all of the loss of water to Walsh Creek. However, Sweat (2001, appendix 1, table 2) reported water-level data for piezometers (shallow observation wells completed to the water table) throughout the study area. None of the piezometers showed a sharp increase or decrease in water level. One piezometer was located in this specific part of the study area, north of C-3 Pool, south of Walsh Creek and east of Walsh Ditch. This piezometer showed a maximum increase of $3.25 \mathrm{ft}$ during winter $1998-99$ and a $4.4 \mathrm{ft}$ overall increase during WY 1999-2000. In neither case was it apparent that the rise in water table was related to spring flooding. Even in these historical worst-case scenarios, infiltration could explain only about half of the water loss from Walsh Creek.

One limitation of the method used to determine flow through Walsh Ditch in WY 2000-04 is its exclusive focus on the northernmost dam on Walsh Ditch, at the Walsh Creek confluence (fig. 5). The method does not provide information on the success of the other eight dams farther south on Walsh Ditch designed to restore overland flow downgradient from the ditch. It is possible that much or all of the water flowing out of Walsh Creek and into Walsh Ditch flows south through Walsh Ditch until it arrives at the many dams in this reach. The diverted water may then flow overland downgradient to the southeast. One way to evaluate this scenario would be to combine measurements from both methods simultaneously, however, data are insufficient to make that evaluation at this time. It is currently uncertain how remediation of Walsh Ditch is affecting erosion in the area of The Spreads (fig. 2, 5) and sedimentation in the Manistique River.

\section{Suggestions for Future Monitoring to Assess Accomplishment of Area- Restoration Goals}

Hydrologic restoration in the study area was intended to accomplish two primary goals: to restore streamflow to Walsh and Marsh Creeks and to restore overland flow downgradient from Walsh Ditch. Restoration of streamflow in Walsh Creek could be monitored by means of streamflow measurements at three easily accessible locations: Walsh Creek at highway M-28, Driggs River at highway M-28, and Driggs River downstream from the Walsh Creek confluence. Overland flow downgradient (southeast) from Walsh Ditch could be monitored by means of additional streamflow mea- 
Table 2. Flows in Driggs River and tributaries, Seney National Wildlife Refuge study area, Michigan.

[Numbers in parentheses in column headings are USGS station/site numbers. All data in feet per second.]

\begin{tabular}{|c|c|c|c|c|c|}
\hline Date & $\begin{array}{c}\text { Walsh Creek at } \\
\text { highway M-28 } \\
\text { (04052500) }\end{array}$ & $\begin{array}{c}\text { Driggs River } \\
\text { at highway } \\
\text { M-28 } \\
\text { (04052000) }\end{array}$ & $\begin{array}{c}\text { Sum of } \\
\text { preced- } \\
\text { ing two } \\
\text { columns }\end{array}$ & $\begin{array}{c}\text { Driggs River Below Walsh } \\
\text { Creek Confluence } \\
(04052600)\end{array}$ & $\begin{array}{c}\text { Net Gain }(+) \\
\text { or Loss }(-)\end{array}$ \\
\hline $3 / 2 / 2000$ & 80.4 & 77.6 & 158 & 98 & -60 \\
\hline $3 / 9 / 2000$ & 116 & 129 & 245 & 174 & -71 \\
\hline $3 / 27 / 2000$ & 123 & 155 & 278 & 209 & -69 \\
\hline $5 / 17 / 2000$ & 6.74 & 65.6 & 72.34 & 72.8 & 0.46 \\
\hline $4 / 15 / 2002$ & 332 & 391 & 723 & 356 & -367 \\
\hline $6 / 4 / 2002$ & 11.8 & 100 & 111.8 & 107 & -4.8 \\
\hline $7 / 18 / 2002$ & 3.38 & 61.2 & 64.58 & 64.5 & -0.08 \\
\hline $9 / 4 / 2002$ & 3.09 & 53.4 & 56.49 & 59.4 & 2.91 \\
\hline \multirow[t]{2}{*}{$9 / 24 / 2002$} & 3.93 & 57.1 & 61.03 & 65.6 & 4.57 \\
\hline & \multicolumn{5}{|c|}{ Dams on Walsh Ditch installed 10/2002 } \\
\hline $11 / 7 / 2002$ & 15.6 & 75.7 & 91.3 & 87.8 & -3.5 \\
\hline $1 / 2 / 2003$ & 8.92 & 64.9 & 73.82 & 67.2 & -6.62 \\
\hline $2 / 11 / 2003$ & 5.8 & 49.9 & 55.7 & 63.1 & 7.4 \\
\hline $4 / 2 / 2003$ & 82.7 & 105 & 187.7 & 172 & -15.7 \\
\hline $4 / 15 / 2003$ & 152 & 190 & 342 & 270 & -72 \\
\hline $5 / 14 / 2003$ & 16.4 & 111 & 127.4 & 137 & 9.6 \\
\hline $7 / 1 / 2003$ & 2.74 & 63.7 & 66.44 & 71.7 & 5.26 \\
\hline $8 / 26 / 2003$ & 3.59 & 50.6 & 54.19 & 59.9 & 5.71 \\
\hline $4 / 16 / 2004$ & 81.6 & 195 & 276.6 & 254 & -22.6 \\
\hline $4 / 19 / 2004$ & 154 & 309 & 463 & 345 & -118 \\
\hline $5 / 6 / 2004$ & 24.4 & 150 & 174.4 & 159 & -15.4 \\
\hline $5 / 20 / 2004$ & 23.2 & 121 & 144.2 & 134 & -10.2 \\
\hline
\end{tabular}

surements of Marsh Creek and Ducey Creek, both at highway M-28, and in Walsh Ditch just before it enters C-3 Pool.

Another way to determine whether overland flow has been restored downgradient of Walsh Ditch is to examine changes in vegetation in the study area. If overland flow is successfully restored, the area will frequently become saturated. Repeated saturation should cause at least some of the current upland tree species in this area to die off within a few years. Vegetation shift can be observed either directly or through a time series of aerial photographs of the study area. Multispectral aerial or satellite imagery could possibly be used to confirm overland flow directly.

\section{Summary and Conclusions}

Historically, much of the land in and near what is now Seney National Wildlife Refuge (NWR) in Michigan's Upper
Peninsula was an expansive ground-water-supported sedge fen (fig. 1). In the 1900s, this land was ditched and diked, severely disrupting the hydrology, and subsequently the ecology of the area. Among other impacts, these actions led to significant erosion, which resulted in deposition of sand into Manistique River and degradation of salmonid spawning habitat (Wilcox and others, in press). Much of the affected area was later incorporated into Seney National Wildlife Refuge and is managed by USFWS. Currently, USFWS is attempting to restore the historical hydrologic regime to part of this affected area in an attempt to revive the once-vast sedge fen and stop erosion in lower Walsh Ditch (fig. 2). This report summarizes previous reports on restoration efforts, presents all streamflow data collected at 20 miscellaneous streamflow measurement sites and 2 streamflow gaging stations (21 locations overall) in the study area from 1998 through 2004, and describes the current understanding of the effectiveness of hydrologic restoration efforts in the C-3 watershed in the refuge. 


\section{Changes in Streamflow Patterns Related to Hydrologic Restoration of a Sedge Fen Wetland in Seney National Wildlife Refuge, Michigan, 1998-2004}

Surface-water flow was monitored at 21 locations near C-3 Pool at the study area before and after construction activities in 2002, which were intended to restore streamflow to Walsh Creek and overland flow downgradient from Walsh Ditch. Because of the remoteness of the study area and a consequent lack of data due to the difficulty of data collection, a water-balance approach was used to evaluate the effectiveness of hydrologic remediation activities.

Results indicate that hydrologic restoration of Walsh Creek was at least partially successful during the 19 months after the installation of the dams on Walsh Ditch. Before installation of the dams, Walsh Creek streamflow was lost whenever streamflow measured at highway M-28 increased to somewhere between 15 and $80 \mathrm{ft}^{3} / \mathrm{s}$. After installation of the dams on Walsh Ditch, flow in Walsh Creek was not lost until streamflow measured at highway M-28 increased to somewhere between 83 and $152 \mathrm{ft}^{3} / \mathrm{s}$. However, as much as $118 \mathrm{ft}^{3} /$ $\mathrm{s}$ of water was lost from Walsh Creek between highway M-28 and Driggs River when Walsh Creek streamflow at highway M-28 exceeded $152 \mathrm{ft}^{3} / \mathrm{s}$. The most likely cause for this loss was water flowing over the banks of Walsh Creek and flowing into Walsh Ditch, bypassing or possibly breaching the upper dam on Walsh Ditch. Alternatively, some water may have been infiltrating the peat substrate or overflowing the banks of Walsh Creek and flowing south to C-3 pool. In the future, restoration of streamflow in Walsh Creek could be assessed by monitoring streamflow at Walsh Creek at highway M-28, Driggs River at highway M-28, and Driggs River downstream from the Walsh Creek confluence.

It is not clear from these data whether overland flow was restored downgradient of Walsh Ditch. However, the presence of overland flow could be assessed by additional monitoring of streamflow at Marsh Creek and Ducey Creek, both at highway M-28, and Walsh Ditch just before it enters C-3 Pool. Alternatively, changes in vegetation downgradient from Walsh Ditch could be monitored by use of remote sensing to assess the restoration of overland flow.

\section{Acknowledgments}

The authors extend their appreciation to several USFWS and USGS personnel who assisted with this investigation. The cooperation of past and current Seney National Wildlife Refuge superintendents Michael Tansy and Tracy Casselman was invaluable. The thoughtful manuscript reviews of Douglas Wilcox and Michael Sweat of the USGS are appreciated. Fieldwork in difficult terrain and under noxious insect conditions by personnel at the Escanaba, Mich., USGS field office and by Stephen Blumer, of the USGS Michigan Water Science Center made this investigation possible.

\section{References}

Boelter, D. H., 1965, Hydraulic conductivity of peats: Soil Science, no. 100, p. 227- 231.

Boelter, D.H., and Verry, E.S., 1977, Peatland and water in the northern lake states: General Technical Report NC-31, St. Paul, Minn., U.S. Department of Agriculture, Forest Service, 22 p.

Ingram, H.A.P., 1983, Hydrology, in Gore, A.J.P., ed., Swamp, Bog, Fen and Moor, Ecosystems of the World: New York, Elsevier, p. 67- 158.

Kowalski, K.P., 2000, Analysis of wetland plant communities and environmental conditions - A wetland restoration project in Seney National Wildlife Refuge: Unpublished Master of Science thesis, Ypsilanti, Mich., Eastern Michigan University, 84 p.

Kowalski, K.P., Wilcox, D.A., 2003, Differences in sedge fen vegetation upstream and downstream from a managed impoundment: American Midland Naturalist v. 150, no. 2, p. 199-200.

National Climate Data Center, 2002, Monthly station normals of temperature, precipitation, and heating and cooling degree days, 1971-2000: Asheville, North Carolina.

Niering, W.A., 1994, Wetlands (6 $6^{\text {th }}$ ed.): New York, Knopf, Audubon Society Nature Guide Series, 638 p.

Rantz, S.E., and others, 1982, Measurement and computation of streamflow - v. 2. computation of discharge: U.S. Geological Survey Water-Supply Paper 2175, p. 285-631.

Smith, R.L., 1992, Elements of Ecology, $3^{\text {rd }}$ ed., New York, HarperCollins, $617 \mathrm{p}$.

Sweat, M.J., 2001, Hydrology of C-3 Watershed, Seney National Wildlife Refuge, Michigan: U.S. Geological Survey Water-Resources Investigations Report 01-4053, $25 \mathrm{p}$.

Wilcox, D.A, Sweat, M.J., Carlson, M.L., and Kowalski, K.P. (in press) A water-budget approach to restoring a sedge fen affected by diking and ditching: Journal of Hydrology. 


\section{Appendix 1}

Streamflow data 
Table 1-A. Streamflow data collected at Seney National Wildlife Refuge, Michigan, 1998-2004.

[ft3/s, cubic feet per second; mi, miles; ft, feet.]

\begin{tabular}{|c|c|c|c|c|}
\hline \multirow[b]{2}{*}{ Station No. } & \multirow[b]{2}{*}{ Stream } & \multirow[b]{2}{*}{ Location } & \multicolumn{2}{|c|}{ Measurements } \\
\hline & & & Date & $\begin{array}{c}\text { Discharge } \\
\left(\mathrm{ft}^{3} / \mathrm{s}\right)\end{array}$ \\
\hline \multicolumn{5}{|c|}{ DRIGGS RIVER MEASUREMENTS } \\
\hline \multicolumn{5}{|c|}{ DRIGGS RIVER NEAR SENEY } \\
\hline 04052000 & Driggs River & $\begin{array}{l}\text { Lat } 46^{\circ} 20^{\prime} 44^{\prime \prime}, \text { long } 86^{\circ} 07^{\prime} 36^{\prime \prime}, \text { in NE1/ } \\
4 \text { NW1/4 sec.36, T.46 N., R.15 W., } \\
\text { Schoolcraft County, Hydrologic Unit } \\
04060106 \text {, at State Highway } 28,8.6 \\
\text { mi west of Seney. }\end{array}$ & $\begin{array}{l}03-02-00 \\
03-09-00 \\
03-27-00 \\
05-17-00 \\
04-16-02 \\
04-23-02 \\
06-05-02 \\
07-18-02 \\
09-05-02 \\
09-24-02 \\
11-07-02 \\
01-02-03 \\
02-12-03 \\
04-02-03 \\
04-15-03 \\
04-22-03 \\
05-14-03 \\
07-01-03 \\
08-27-03\end{array}$ & $\begin{array}{l}77.6 \\
129 \\
173 \\
* 65.6 \\
391 \\
195 \\
100 \\
61.2 \\
53.4 \\
59.5 \\
75.8 \\
64.9 \\
52.3 \\
105 \\
190 \\
314 \\
111 \\
63.4 \\
50.6\end{array}$ \\
\hline \multicolumn{5}{|c|}{ DRIGGS RIVER NEAR C3 POOL NEAR DIVERSION DITCH NEAR SENEY } \\
\hline 04052010 & Driggs River & $\begin{array}{l}\text { Lat } 46^{\circ} 18^{\prime} 58^{\prime \prime}, \text { long } 86^{\circ} 06^{\prime} 32 " \text {, in NE1/ } \\
4 \text { NW1/4 sec.7, T.45 N., R.14 W., } \\
\text { Schoolcraft County, Hydrologic Unit } \\
04060106,150 \mathrm{ft} \text { downstream from } \\
\text { Diversion Ditch at Seney National } \\
\text { Wildlife Refuge, } 8.0 \text { mi west of } \\
\text { Seney. As of 2002, station number } \\
\text { published as } 04052600 .\end{array}$ & $\begin{array}{l}03-02-00 \\
03-09-00 \\
03-28-00 \\
05-17-00\end{array}$ & $\begin{array}{l}98.0 \\
174 \\
209 \\
* 72.8\end{array}$ \\
\hline \multicolumn{5}{|c|}{ DRIGGS RIVER APPROX. 7 MI BELOW DIVERSION DITCH } \\
\hline 04052040 & Driggs River & $\begin{array}{l}\text { Lat } 46^{\circ} 13^{\prime} 56^{\prime \prime}, \text { long } 86^{\circ} 02^{\prime} 12^{\prime} \text {, in SE1/4 } \\
\text { SE1/4 sec.3, T.44 N., R.14 W., } \\
\text { Schoolcraft County, Hydrologic Unit } \\
04060106,0.8 \text { mi southwest of M } \\
\text { Pool at Seney National Wildlife Ref- } \\
\text { uge, } 5.5 \text { mi west of Germfask. As of } \\
\text { 2002, station number published as } \\
04052730 .\end{array}$ & $\begin{array}{l}03-08-00 \\
03-28-00 \\
05-17-00\end{array}$ & $\begin{array}{l}153 \\
215 \\
* 85.8\end{array}$ \\
\hline \multicolumn{5}{|c|}{ DRIGGS RIVER APPROX. 7 MI BELOW DIVERSION DITCH } \\
\hline 04052730 & Driggs River & $\begin{array}{l}\text { Lat } 46^{\circ} 13^{\prime} 56^{\prime \prime}, \text { long } 86^{\circ} 02^{\prime} 12^{\prime \prime} \text {, in SE1/4 } \\
\text { SE1/4 sec.3, T.44 N., R.14 W., } \\
\text { Schoolcraft County, Hydrologic Unit } \\
04060106,0.8 \text { mi southwest of M } \\
\text { Pool at Seney National Wildlife Ref- } \\
\text { uge, } 5.5 \text { mi west of Germfask. Previ- } \\
\text { ously published as station number } \\
04052040 .\end{array}$ & $\begin{array}{l}04-16-02 \\
04-23-02 \\
06-05-02 \\
07-18-02 \\
09-04-02 \\
09-24-02 \\
11-07-02 \\
01-02-03 \\
02-12-03 \\
04-22-03 \\
05-14-03 \\
07-01-03 \\
08-27-03\end{array}$ & $\begin{array}{c}\text { a354 } \\
\text { a258 } \\
\text { a116 } \\
\text { a77.5 } \\
\text { a67.9 } \\
\text { a76.4 } \\
\text { a102 } \\
\text { a64.2 } \\
\text { a64.5 } \\
\text { a500 } \\
\text { a167 } \\
\text { a77.1 } \\
\text { a73.0 }\end{array}$ \\
\hline
\end{tabular}


Table 1-A. Streamflow data collected at Seney National Wildlife Refuge, Michigan, 1998-2004, continued.

\begin{tabular}{|c|c|c|c|c|}
\hline \multirow[b]{2}{*}{ Station No. } & \multirow[b]{2}{*}{ Stream } & \multirow[b]{2}{*}{ Location } & \multicolumn{2}{|c|}{ Measurements } \\
\hline & & & Date & $\begin{array}{c}\text { Discharge } \\
\left(\mathrm{ft}^{3} / \mathrm{s}\right)\end{array}$ \\
\hline \multicolumn{5}{|c|}{ WALSH CREEK MEASUREMENTS } \\
\hline \multicolumn{5}{|c|}{ WALSH CREEK NEAR SENEY } \\
\hline 04052500 & Walsh Creek & $\begin{array}{l}\text { Lat } 46^{\circ} 20^{\prime} 44 " \text {, long } 86^{\circ} 10^{\prime} 37^{\prime \prime}, \text { in NW1/4 } \\
\text { NW1/4 sec.34, T.46 N., R.15 W., } \\
\text { Schoolcraft County, Hydrologic Unit } \\
04060106 \text {, at State Highway } 28,11.1 \mathrm{mi} \\
\text { west of Seney. }\end{array}$ & $\begin{array}{l}09-16-98 \\
10-28-98 \\
12-09-98 \\
04-05-99 \\
04-13-99 \\
04-28-99 \\
06-02-99 \\
06-30-99 \\
08-24-99 \\
09-20-99 \\
03-02-00 \\
03-10-00 \\
03-27-00 \\
05-18-00\end{array}$ & $\begin{array}{c}* 3.09 \\
* 6.01 \\
* 13.3 \\
197 \\
66.0 \\
* 13.4 \\
19.2 \\
* 2.91 \\
* 2.18 \\
* 1.62 \\
80.4 \\
116 \\
123 \\
* 6.74\end{array}$ \\
\hline \multicolumn{5}{|c|}{ WALSH CREEK BELOW CONTROL STRUCTURE ABOVE CONFLUENCE W/DRIGGS RIVER } \\
\hline 04052510 & Walsh Creek & $\begin{array}{l}\text { Lat } 46^{\circ} 19^{\prime} 08^{\prime \prime} \text {, long } 86^{\circ} 07^{\prime} 06^{\prime \prime}, \text { in SE1/4 } \\
\text { SE1/4 sec.1, T.45 N., R.15 W., School- } \\
\text { craft County, Hydrologic Unit } \\
04060106 \text {, downstream from control } \\
\text { structure upstream from Driggs River, } \\
8.5 \text { mi southwest of Seney. }\end{array}$ & $\begin{array}{l}04-02-03 \\
04-03-03 \\
08-08-03 \\
08-27-03 \\
09-26-03\end{array}$ & $\begin{array}{l}\text { a54.4 } \\
\text { a44.9 } \\
\text { a8.14 } \\
\text { a1.16 } \\
\text { a14.5 }\end{array}$ \\
\hline \multicolumn{5}{|c|}{ SWEENEY CREEK MEASUREMENTS } \\
\hline \multicolumn{5}{|c|}{ SWEENEY CREEK AT OUTLET OF C3 POOL AT SENEY REFUGE } \\
\hline 04052700 & Sweeney Creek & $\begin{array}{l}\text { Lat } 46^{\circ} 18^{\prime} 02 " \text {, long } 86^{\circ} 07^{\prime} 18^{\prime \prime} \text {, in NW1/4 } \\
\text { NE1/4 sec.13, T.45 N., R.15 W., } \\
\text { Schoolcraft County, Hydrologic Unit } \\
04060106 \text {, at outlet of C3 Pool, at Seney } \\
\text { National Wildlife Refuge, } 9.0 \text { mi south- } \\
\text { west of Seney. }\end{array}$ & $\begin{array}{l}09-16-98 \\
10-27-98 \\
12-10-98 \\
04-06-99 \\
04-14-99 \\
04-28-99 \\
06-02-99 \\
08-24-99 \\
09-20-99 \\
03-02-00 \\
03-08-00 \\
03-28-00 \\
05-18-00\end{array}$ & $\begin{array}{c}\text { a7.86 } \\
\text { a0.32 } \\
\text { a26.7 } \\
\text { a195 } \\
\text { a54.4 } \\
\text { a19.0 } \\
\text { a14.9 } \\
\text { a1.24 } \\
\text { ae0.80 } \\
\text { a119 } \\
\text { a186 } \\
\text { a182 } \\
\text { a6.50 }\end{array}$ \\
\hline \multicolumn{5}{|c|}{ SWEENEY CREEK AT CONFLUENCE WITH SWEENEY DITCH } \\
\hline 04052704 & Sweeney Creek & $\begin{array}{l}\text { Lat } 46^{\circ} 17^{\prime} 47^{\prime \prime} \text {, long } 86^{\circ} 06^{\prime} 50^{\prime \prime}, \text { in SW1/4 } \\
\text { NW1/4 sec.18, T.45 N., R.14 W., } \\
\text { Schoolcraft County, Hydrologic Unit } \\
04060106,0.6 \text { mi downstream from C3 } \\
\text { Pool at Seney National Wildlife Refuge, } \\
8.7 \text { mi southwest of Seney. }\end{array}$ & $05-18-00$ & a8.23 \\
\hline
\end{tabular}


Table 1-A. Streamflow data collected at Seney National Wildlife Refuge, Michigan, 1998-2004, continued.

\begin{tabular}{|c|c|c|c|c|}
\hline \multirow[b]{2}{*}{ Station No. } & \multirow[b]{2}{*}{ Stream } & \multirow[b]{2}{*}{ Location } & \multicolumn{2}{|c|}{ Measurements } \\
\hline & & & Date & $\begin{array}{c}\text { Discharge } \\
\left(\mathrm{ft}^{3} / \mathrm{s}\right)\end{array}$ \\
\hline \multicolumn{5}{|c|}{ MARSH CREEK MEASUREMENTS } \\
\hline \multicolumn{5}{|c|}{ MARSH CREEK AT HIGHWAY M28 NEAR SHINGLETON } \\
\hline 04053500 & Marsh Creek & $\begin{array}{l}\text { Lat } 46^{\circ} 20^{\prime} 45^{\prime \prime} \text {, long } 86^{\circ} 14^{\prime} 09^{\prime \prime}, \text { in NW1/4 } \\
\text { NW1/4 sec.31, T.46 N., R.15 W., } \\
\text { Schoolcraft County, Hydrologic Unit } \\
04060106 \text {, at State Highway } 28,14.0 \mathrm{mi} \\
\text { west of Seney. }\end{array}$ & $\begin{array}{l}09-16-98 \\
10-28-98 \\
12-09-98 \\
04-05-99 \\
04-13-99 \\
04-28-99 \\
06-02-99 \\
06-30-99 \\
08-24-99 \\
09-20-99 \\
03-02-00 \\
03-08-00 \\
03-27-00 \\
04-15-02 \\
04-25-02 \\
06-04-02 \\
11-07-02 \\
04-15-03 \\
04-22-03 \\
05-15-03\end{array}$ & $\begin{array}{c}* 0.05 \\
* 0.00 \\
* 2.55 \\
18.4 \\
11.0 \\
* 2.72 \\
0.85 \\
* 0.00 \\
* 0.00 \\
* 0.00 \\
12.4 \\
11.2 \\
11.9 \\
18.9 \\
19.3 \\
0.0 \\
2.12 \\
14.1 \\
17.3 \\
4.84\end{array}$ \\
\hline \multicolumn{5}{|c|}{ MARSH CREEK AT OUTLET OF C3 POOL } \\
\hline 04053600 & Marsh Creek & $\begin{array}{l}\text { Lat } 46^{\circ} 17^{\prime} 22 " \text {, long } 86^{\circ} 08^{\prime} 38 " \text {, in SW1/4 } \\
\text { SE1/4 sec.14, T.45 N., R.15 W., School- } \\
\text { craft County, Hydrologic Unit } \\
04060106 \text {, at outlet of C3 Pool at Seney } \\
\text { National Wildlife Refuge, } 10.3 \mathrm{mi} \\
\text { southwest of Seney. }\end{array}$ & $\begin{array}{l}07-06-99 \\
07-06-99 \\
07-06-99 \\
07-07-99 \\
08-24-99 \\
03-02-00 \\
03-08-00 \\
03-28-00 \\
05-17-00 \\
04-15-02 \\
04-24-02 \\
06-04-02 \\
07-18-02 \\
09-05-02 \\
01-02-03 \\
04-03-03 \\
07-01-03 \\
08-08-03 \\
08-27-03 \\
09-26-03\end{array}$ & $\begin{array}{c}\text { a19.1 } \\
\text { a } 26.5 \\
\text { a28.5 } \\
\text { a31.0 } \\
\text { a2.72 } \\
\text { a34.2 } \\
\text { a30.5 } \\
\text { a31.0 } \\
\text { a5.44 } \\
\text { a } 45.9 \\
\text { a36.1 } \\
\text { a27.8 } \\
\text { a14.8 } \\
\text { a } 7.74 \\
\text { a10.2 } \\
\text { a90.5 } \\
\text { a0.42 } \\
\text { a15.1 } \\
\text { a2.11 } \\
\text { a12.3 }\end{array}$ \\
\hline
\end{tabular}


Table 1-A. Streamflow data collected at Seney National Wildlife Refuge, Michigan, 1998-2004, continued.

\begin{tabular}{|c|c|c|c|c|}
\hline \multirow[b]{2}{*}{ Station No. } & \multirow[b]{2}{*}{ Stream } & \multirow[b]{2}{*}{ Location } & \multicolumn{2}{|c|}{ Measurements } \\
\hline & & & Date & $\begin{array}{c}\text { Discharge } \\
\quad\left(\mathrm{ft}^{3} / \mathrm{s}\right)\end{array}$ \\
\hline \multicolumn{5}{|c|}{ DUCEY CREEK MEASUREMENTS } \\
\hline \multicolumn{5}{|c|}{ DUCEY CREEK NEAR SENEY } \\
\hline 04053520 & Ducey Creek & $\begin{array}{l}\text { Lat } 46^{\circ} 20^{\prime} 44 " \text {, long } 86^{\circ} 13 ' 31 ", \text { in NW1/4 } \\
\text { NE1/4 sec.31, T. } 46 \text { N., R. } 15 \text { W., } \\
\text { Schoolcraft County, Hydrologic Unit } \\
04060106 \text {, at railroad bridge } 150 \mathrm{ft} \\
\text { downstream from State Highway } 28 \text {, } \\
13.5 \text { mi west of Seney. }\end{array}$ & $\begin{array}{l}09-16-98 \\
12-09-98 \\
04-05-99 \\
04-13-99 \\
04-28-99 \\
06-02-99 \\
06-30-99 \\
08-24-99 \\
09-20-99 \\
03-02-00 \\
03-08-00 \\
03-27-00\end{array}$ & $\begin{array}{l}* 0.00 \\
* 8.08 \\
92.1 \\
41.4 \\
* 5.38 \\
10.3 \\
* 0.00 \\
* 0.00 \\
* 0.00 \\
57.9 \\
59.7 \\
75.8\end{array}$ \\
\hline \multicolumn{5}{|c|}{ WALSH DITCH MEASUREMENTS } \\
\hline \multicolumn{5}{|c|}{ WALSH DITCH DOWNSTREAM FROM HIGHWAY M28 } \\
\hline 04054415 & Walsh Ditch & $\begin{array}{l}\text { Lat } 46^{\circ} 19^{\prime} 38^{\prime \prime}, \text { long } 86^{\circ} 09^{\prime} 26^{\prime \prime}, \text { in SE1/4 } \\
\text { NE1/4 sec.3, T.45 N., R.15 W., School- } \\
\text { craft County, Hydrologic Unit } \\
04060106,2.5 \text { mi upstream from C3 } \\
\text { Pool at Seney National Wildlife Refuge, } \\
10.2 \text { mi west of Seney. }\end{array}$ & $09-19-00$ & 4.84 \\
\hline \multicolumn{5}{|c|}{ WALSH DITCH UPSTREAM FROM C3 POOL AT SENEY REFUGE } \\
\hline 04054420 & Walsh Ditch & $\begin{array}{l}\text { Lat } 46^{\circ} 17^{\prime} 36^{\prime \prime}, \text { long } 86^{\circ} 09^{\prime} 30^{\prime \prime}, \text { in NE1/4 } \\
\text { SE1/4 sec. } 15 \text {, T.45 N., R.15 W., School- } \\
\text { craft County, Hydrologic Unit } \\
04060106,0.2 \text { mi upstream from C3 } \\
\text { Pool at Seney National Wildlife Refuge, } \\
10.7 \text { mi southwest of Seney. }\end{array}$ & $\begin{array}{l}09-16-98 \\
10-27-98 \\
12-09-98 \\
04-06-99 \\
04-13-99 \\
04-29-99 \\
06-03-99 \\
06-29-99 \\
08-24-99 \\
09-20-99 \\
03-02-00 \\
03-08-00 \\
03-27-00 \\
05-17-00\end{array}$ & $\begin{array}{l}* 7.85 \\
* 11.3 \\
* 28.2 \\
305 \\
147 \\
* 32.4 \\
32.5 \\
* 8.12 \\
* 7.56 \\
* 0.00 \\
176 \\
204 \\
208 \\
* 20.4\end{array}$ \\
\hline \multicolumn{5}{|c|}{ WALSH DITCH AT OUTLET OF C3 POOL AT SENEY REFUGE } \\
\hline 04054425 & Walsh Ditch & $\begin{array}{l}\text { Lat } 46^{\circ} 17^{\prime} 20^{\prime \prime} \text {, long } 86^{\circ} 09^{\prime} 10^{\prime \prime}, \text { in SW1/4 } \\
\text { SW1/4 sec. } 14 \text {, T. } 45 \text { N., R.15 W., } \\
\text { Schoolcraft County, Hydrologic Unit } \\
04060106 \text {, at outlet of C3 Pool at Seney } \\
\text { National Wildlife Refuge, } 10.6 \mathrm{mi} \\
\text { southwest of Seney. }\end{array}$ & $\begin{array}{c}09-16-98 \\
10-27-98 \\
12-10-98 \\
04-06-99 \\
04-14-99 \\
06-03-99 \\
06-30-99 \\
08-24-99 \\
09-20-99 \\
03-02-00 \\
03-08-00 \\
03-28-00 \\
05-17-00\end{array}$ & $\begin{array}{c}\mathrm{a} 0.04 \\
\mathrm{a} 0.15 \\
\mathrm{a} 0.07 \\
\mathrm{a} 300 \\
\mathrm{a} 98.0 \\
\mathrm{a} 10.2 \\
\mathrm{a} 0.02 \\
\mathrm{a} 0.04 \\
\mathrm{a} 0.03 \\
\mathrm{a} 37.5 \\
\mathrm{a} 51.3 \\
\mathrm{a} 43.4 \\
\mathrm{a}<0.01\end{array}$ \\
\hline
\end{tabular}


Table 1-A. Streamflow data collected at Seney National Wildlife Refuge, Michigan, 1998-2004, continued.

\begin{tabular}{|c|c|c|c|c|}
\hline \multirow[b]{2}{*}{ Station No. } & \multirow[b]{2}{*}{ Stream } & \multirow[b]{2}{*}{ Location } & \multicolumn{2}{|c|}{ Measurements } \\
\hline & & & Date & $\begin{array}{c}\text { Discharge } \\
\quad\left(\mathrm{ft}^{3} / \mathrm{s}\right)\end{array}$ \\
\hline \multicolumn{5}{|c|}{ WALSH DITCH NEAR GERMFASK } \\
\hline 04054428 & Walsh Ditch & $\begin{array}{l}\text { Lat } 46^{\circ} 16^{\prime} 37^{\prime \prime} \text {, long } 86^{\circ} 09^{\prime} 27^{\prime \prime} \text {, in SW1/4 } \\
\text { SW1/4 sec.23, T.45 N., R.15 W., } \\
\text { Schoolcraft County, Hydrologic Unit } \\
04060106,1.0 \text { mi downstream from C3 } \\
\text { Pool at Seney Wildlife Refuge, } 11.3 \text { mi } \\
\text { southwest of Seney. }\end{array}$ & 06-03-99 & a9.10 \\
\hline
\end{tabular}

EAST CHANNEL WALSH DITCH NEAR GERMFASK

\begin{tabular}{|c|c|c|c|c|}
\hline 04054429 & $\begin{array}{l}\text { Walsh Ditch (East } \\
\text { Channel) }\end{array}$ & $\begin{array}{l}\text { Lat } 46^{\circ} 15^{\prime} 55^{\prime \prime} \text {, long } 86^{\circ} 09^{\prime} 20^{\prime \prime} \text {, in NW1/4 } \\
\text { SW1/4 sec.26, T.45 N., R.15 W., } \\
\text { Schoolcraft County, Hydrologic Unit } \\
04060106,1.8 \text { mi downstream from C3 } \\
\text { Pool at Seney National Wildlife Refuge, } \\
11.1 \text { mi west of Germfask. }\end{array}$ & 09-19-00 & a1.27 \\
\hline \multicolumn{5}{|c|}{ WEST CHANNEL WALSH DITCH NEAR GERMFASK } \\
\hline 04054430 & $\begin{array}{l}\text { Walsh Ditch (West } \\
\text { Channel) }\end{array}$ & $\begin{array}{l}\text { Lat } 46^{\circ} 15^{\prime} 53 " \text { ", long } 86^{\circ} 09^{\prime} 31 " \text {, in NE1/4 } \\
\text { SE1/4 sec. } 27, \text { T. } 45 \text { N., R.15 W., School- } \\
\text { craft County, Hydrologic Unit } \\
04060106,1.9 \text { mi downstream from C3 } \\
\text { Pool at Seney National Wildlife Refuge, } \\
11.2 \text { mi west of Germfask. }\end{array}$ & 09-19-00 & a0.19 \\
\hline
\end{tabular}

WALSH DITCH ABOVE MARSH CREEK CONFLUENCE

$\begin{array}{ll}04054434 \quad \text { Walsh Ditch } & \text { Lat } 46^{\circ} 14^{\prime} 43 ", \text { long } 86^{\circ} 07^{\prime} 01 ", \text { in SE1/4 } \\ & \text { SE1/4 sec.36, T.45 N., R.15 W., School- } \\ & \text { craft County, Hydrologic Unit } \\ & \text { 04060106, immediately upstream from } \\ & \text { confluence with Marsh Creek, } 8.8 \mathrm{mi} \\ & \text { west of } \\ & \text { Germfask. }\end{array}$

WALSH DITCH BELOW MARSH CREEK CONFLUENCE

\begin{tabular}{|c|c|c|c|}
\hline 04054435 & Walsh Ditch & $\begin{array}{l}\text { Lat } 46^{\circ} 14 ' 43^{\prime \prime}, \text { long } 86^{\circ} 06^{\prime} 58^{\prime \prime}, \text { in SE1/4 } \\
\text { SE1/4 sec.36, T.45 N., R.15 W., School- } \\
\text { craft County, Hydrologic Unit } \\
04060106 \text {, immediately downstream } \\
\text { from confluence with Marsh Creek, } 8.8 \\
\text { mi west of } \\
\text { Germfask. }\end{array}$ & $07-12-99$ \\
\hline
\end{tabular}

WALSH DITCH (LOWER) AT SENEY REFUGE

\begin{tabular}{|c|c|c|c|c|}
\hline 04054440 & Walsh Ditch & $\begin{array}{l}\text { Lat } 46^{\circ} 11^{\prime} 05^{\prime} \text {, long } 86^{\circ} 066^{\prime} 59^{\prime \prime} \text {, in NE1/4 } \\
\text { sec. } 25 \text {, T. } 44 \text { N., R. } 15 \text { W., Schoolcraft } \\
\text { County, Hydrologic Unit } 04060106 \text {, at } \\
\text { Seney Wildlife Refuge, } 9.5 \text { mi south- } \\
\text { west of } \\
\text { Germfask. }\end{array}$ & 07-06-99 & a13.4 \\
\hline
\end{tabular}

\footnotetext{
* Base flow.

a Affected by regulation and/or diversion.

c Discharge measurement made by employees of U.S. Geological Survey, Biological Resources Division.

e Estimated.
} 
Table 1-B. Streamflow data collected at Walsh Creek at M-28 near Seney, Michigan.

[ft3/s, cubic feet per second; mi, miles; ft, feet.] Source: http://waterdata.usgs.gov/nwis.

04052500 WALSH CREEK AT M-28 NEAR SENEY, MI

\begin{tabular}{|c|c|c|c|c|c|c|c|c|c|c|c|c|}
\hline \multicolumn{13}{|c|}{ DRAINAGE AREA.--12 mi², approximately. } \\
\hline \multicolumn{13}{|c|}{ PERIOD OF RECORD.--April 1938 to April 1942; periodic discharge measurements 1943-2002; August 2002 to September 2003 (discontinued). } \\
\hline \multicolumn{13}{|c|}{ GAGE.--Water-stage recorder. Elevation of gage is $775 \mathrm{ft}$ above sea level. Prior to April 30, 1942, non-recording gage at same site and datum. } \\
\hline \multicolumn{13}{|c|}{ REMARKS.--Records good except for estimated daily discharges, which are fair. Several measurements of water temperature were made during the year. } \\
\hline & & & SHARC & JBIC & ER S & $\begin{array}{l}\text { ND, WA } \\
\text { IILY M }\end{array}$ & $\begin{array}{l}\text { YEAR } \\
\text { VALU }\end{array}$ & OBER & & & & \\
\hline DAY & OCT & NOV & DEC & JAN & FEB & MAR & APR & MAY & JUN & JUL & AUG & SEP \\
\hline 1 & --- & --- & --- & --- & --- & --- & --- & --- & --- & --- & 28 & 3.3 \\
\hline 2 & --- & --- & --- & --- & --- & --- & --- & --- & --- & --- & 47 & 3.3 \\
\hline 3 & --- & --- & --- & --- & --- & --- & --- & --- & --- & -- & 28 & 3.2 \\
\hline 4 & --- & --- & --- & --- & --- & --- & --- & --- & --- & --- & 21 & 3.1 \\
\hline 5 & --- & --- & --- & --- & --- & --- & --- & --- & --- & --- & 17 & 3.1 \\
\hline 6 & --- & --- & --- & --- & --- & --- & --- & --- & --- & --- & 14 & 3.1 \\
\hline 7 & --- & --- & --- & --- & --- & --- & --- & --- & --- & --- & 12 & 3.0 \\
\hline 8 & --- & --- & --- & --- & --- & --- & --- & --- & --- & --- & 10 & 2.9 \\
\hline 9 & --- & --- & --- & --- & --- & --- & --- & --- & --- & --- & 9.0 & 2.8 \\
\hline 10 & --- & --- & --- & --- & --- & --- & --- & --- & --- & --- & 8.1 & 2.8 \\
\hline 11 & --- & --- & --- & --- & --- & --- & --- & --. & --- & --- & 7.3 & 2.7 \\
\hline 12 & --- & --- & --- & --- & --- & --- & --- & --- & --- & --- & 6.8 & 2.6 \\
\hline 13 & --- & --- & --- & --- & --- & --- & --- & --- & --- & --- & 7.2 & 2.6 \\
\hline 14 & --- & --- & --- & --- & --- & --- & --- & --- & --- & --- & 7.3 & 2.8 \\
\hline 15 & --- & --- & --- & --- & --- & --- & --- & --- & --- & --- & 6.6 & 3.1 \\
\hline 16 & --- & --- & --- & --- & --- & --- & --- & --- & --- & --- & 6.2 & 2.9 \\
\hline 17 & --- & --- & --- & --- & --- & --- & --- & --- & --- & --- & 6.1 & 2.7 \\
\hline 18 & --- & --- & --- & --- & --- & --- & --- & --- & --- & --- & 5.8 & 2.7 \\
\hline 19 & --- & --- & --- & --- & --- & --- & --- & --- & --- & --- & 5.3 & 3.1 \\
\hline 20 & --- & --- & --- & --- & --- & --- & --- & --- & --- & --- & 4.7 & 3.4 \\
\hline 21 & --- & --- & --- & --- & --- & --- & --- & --- & --- & --- & 5.4 & 3.8 \\
\hline 22 & --- & --- & --- & --- & --- & --- & --- & --- & --- & --- & 6.4 & 3.5 \\
\hline 23 & --- & --- & --- & --- & --- & --- & --- & --- & --- & --- & 5.7 & 3.4 \\
\hline 24 & --- & --- & --- & --- & --- & --- & --- & --- & --- & --- & 5.4 & 4.2 \\
\hline 25 & --- & --- & --- & --- & --- & --- & --- & --- & --- & --- & 4.9 & 4.0 \\
\hline 26 & --- & --. & --. & --. & --- & --- & --- & --- & --- & --. & 4.7 & 4.2 \\
\hline 27 & --- & --- & --- & --- & --- & --- & --- & --- & --- & --- & 4.3 & 4.5 \\
\hline 28 & --- & --- & --- & --- & --- & --- & --- & --- & --- & --- & 4.1 & 4.1 \\
\hline 29 & --- & --- & --- & --- & --- & --- & --- & --- & --- & --- & 3.8 & 3.9 \\
\hline 30 & --- & --- & --- & --- & --- & --- & --- & --- & --- & --- & 3.6 & 4.0 \\
\hline 31 & --- & --- & --- & --- & --- & --- & --- & --- & --- & --- & 3.5 & \\
\hline
\end{tabular}

DISCHARGE, CUBIC FEET PER SECOND, WATER YEAR OCTOBER 2002 TO SEPTEMBER 2003

\begin{tabular}{|c|c|c|c|c|c|c|c|c|c|c|c|c|}
\hline \multirow[b]{2}{*}{ DAY } & \multirow[b]{2}{*}{ OCT } & \multirow[b]{2}{*}{ NOV } & . & & & ILY M & ALU & & & & & \\
\hline & & & DEC & JAN & FEB & MAR & APR & MAY & JUN & JUL & AUG & SEP \\
\hline 1 & 12 & 15 & 12 & e9.0 & e6.0 & e5.5 & 81 & 33 & 12 & 2.7 & $\begin{array}{r}10 \\
92\end{array}$ & 2.9 \\
\hline 2 & 9.4 & 15 & 11 & e9.0 & e6.0 & e5.5 & 77 & 28 & 9.9 & 2.5 & 9.2 & 2.8 \\
\hline 3 & 7.6 & 14 & 11 & 8.7 & e6.0 & e5.5 & 71 & 25 & 8.4 & 2.4 & 9.5 & 2.6 \\
\hline 4 & 19 & 15 & 10 & 7.9 & e6.0 & e5.5 & 64 & 22 & 7.3 & 2.7 & 11 & 2.7 \\
\hline 5 & 40 & 15 & 10 & 7.6 & e6.0 & $\mathrm{e} 5.5$ & 57 & 20 & 6.8 & 3.4 & 9.6 & 2.6 \\
\hline 6 & 37 & 17 & 9.9 & 7.4 & e6.0 & e5.5 & 52 & 21 & 6.3 & 3.0 & 9.2 & 2.5 \\
\hline 7 & 52 & 16 & 9.8 & 7.4 & e6.0 & $\mathrm{e} 5.5$ & 47 & 20 & 6.8 & 3.0 & 8.6 & 2.4 \\
\hline 8 & 51 & 16 & 9.7 & 7.6 & e6.0 & e5.5 & 43 & 18 & 7.3 & 3.8 & 7.9 & 2.3 \\
\hline 9 & 63 & 16 & 9.4 & e7.5 & e6.0 & e5.5 & 43 & 16 & 6.9 & 3.3 & 7.2 & 2.3 \\
\hline 10 & 52 & 22 & 9.3 & $\mathrm{e} 7.5$ & e6.0 & $\mathrm{e} 5.5$ & 52 & 16 & 7.5 & 4.7 & 6.4 & 2.2 \\
\hline 11 & 40 & 31 & 9.2 & e7.0 & e6.0 & e5.5 & 75 & 19 & 12 & 12 & 6.0 & 2.2 \\
\hline 12 & 37 & 27 & 9.1 & e 7.0 & e6.0 & $\mathrm{e} 5.5$ & 102 & 23 & 10 & 9.6 & 5.4 & 2.1 \\
\hline 13 & 50 & 25 & 9.1 & e 7.0 & e6.0 & e5.5 & 108 & 22 & 8.4 & 6.9 & 4.7 & 2.5 \\
\hline 14 & 41 & 24 & 9.1 & $\mathrm{e} 7.0$ & e6.0 & $\mathrm{e} 5.5$ & 123 & 19 & 7.2 & 6.4 & 4.4 & 6.6 \\
\hline 15 & 35 & 22 & 9.1 & e7.0 & e6.0 & e6.0 & 161 & 16 & 6.5 & 14 & 4.1 & 16 \\
\hline 16 & 30 & 17 & 8.9 & e7.0 & e6.0 & e7.0 & 153 & 15 & 5.9 & 15 & 3.8 & 21 \\
\hline 17 & 25 & 13 & 8.5 & e6.5 & e6.0 & e7.5 & 119 & 14 & 5.4 & 9.9 & 3.6 & 14 \\
\hline 18 & 22 & 12 & 9.1 & e6.5 & e6.0 & e9.0 & 107 & 13 & 5.1 & 7.5 & 3.4 & 11 \\
\hline 19 & 25 & 15 & 19 & e6.5 & e6.0 & e12 & 100 & 12 & 4.7 & 6.1 & 3.3 & 9.2 \\
\hline 20 & 23 & 16 & 21 & e6.5 & e6.0 & e15 & 184 & 14 & 4.2 & 17 & 3.2 & 7.7 \\
\hline 21 & 22 & 15 & 20 & e6.5 & e5.5 & e20 & 225 & 13 & 4.0 & 48 & 3.2 & 6.8 \\
\hline 22 & 23 & 15 & 19 & e6.0 & $\mathrm{e} 5.5$ & $\mathrm{e} 25$ & 163 & 11 & 3.7 & 75 & 3.1 & 12 \\
\hline 23 & 24 & 14 & 18 & e6.0 & e5.5 & e30 & 113 & 10 & 3.4 & 51 & 2.9 & 18 \\
\hline 24 & 21 & 14 & 17 & e6.0 & e5.5 & $\mathrm{e} 45$ & 90 & 9.6 & 3.2 & 34 & 2.9 & 15 \\
\hline 25 & 19 & 13 & e15 & e6.0 & e5.5 & $\mathrm{e} 55$ & 76 & 8.8 & 3.1 & 23 & 2.9 & 17 \\
\hline 26 & 19 & 13 & e14 & e6.0 & $\mathrm{e} 5.5$ & e65 & 64 & 8.1 & 3.1 & 21 & 3.3 & 22 \\
\hline 27 & 19 & 12 & e13 & e6.0 & e5.5 & 76 & 55 & 7.2 & 3.1 & 18 & 3.1 & 65 \\
\hline 28 & 18 & 11 & $\mathrm{e} 11$ & e6.0 & $\mathrm{e} 5.5$ & 97 & 49 & 7.0 & 3.0 & 15 & 3.1 & 78 \\
\hline 29 & 17 & 11 & e10 & e 6.0 & --. & 101 & 43 & 7.1 & 2.9 & 12 & 3.7 & 68 \\
\hline 30 & 16 & 12 & e10 & e6.0 & --- & 92 & 37 & 8.4 & 2.8 & 11 & 3.3 & 56 \\
\hline & 15 & & & & 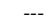 & 87 & & & & & & \\
\hline
\end{tabular}

(e) Estimated. 


\section{Table 1-C. Streamflow data collected at Driggs River near C-3 Pool near diversion ditch near} Seney, Michigan.

[ft3/s, cubic feet per second; mi, miles; ft, feet.] Source: http://waterdata.usgs.gov/nwis.

04052600 DRIGGS RIVER NEAR C-3 POOL NEAR DIVERSION DITCH NEAR SENEY, MI LOCATION.--Lat $46^{\circ} 18^{\prime} 58^{\prime \prime}$, long $86^{\circ} 06^{\prime} 32 "$, in NE1/4 NW1/4 sec.7, T.45 N., R.14 W., Schoolcraft County, Hydrologic Unit 04060106, $150 \mathrm{ft}$ downstream from
Diversion Ditch at Seney National Wildlife Refuge, 8 mi west of Seney.

DRAINAGE AREA.--Not determined.

PERIOD OF RECORD.--March 2000 to May 2000 (discharge measurements only, station 04052010), August 2002 to September 2003 (discontinued).

GAGE.--Water-stage recorder. Elevation of gage is $731.46 \mathrm{ft}$ above sea level.

REMARKS.--Records fair except for estimated daily discharges, which are poor. Flow can be regulated by Diversion Ditch, $150 \mathrm{ft}$ upstream of gage or at control structure at confluence of Walsh Creek, $.25 \mathrm{mi}$ upstream. Several measurements of water temperature were made during the year.

DISCHARGE, CUBIC FEET PER SECOND, WATER YEAR OCTOBER 2001 TO SEPTEMBER 2002

\begin{tabular}{|c|c|c|c|c|c|c|c|c|c|c|c|c|}
\hline DAY & OCT & NOV & DEC & JAN & FEB & MAR & APR & MAY & JUN & JUL & AUG & SEP \\
\hline $\begin{array}{l}1 \\
2 \\
3 \\
4 \\
5\end{array}$ & $\begin{array}{c}--- \\
--- \\
--- \\
---\end{array}$ & $\begin{array}{c}--- \\
--- \\
--- \\
---\end{array}$ & $\begin{array}{l}--- \\
--- \\
--- \\
--- \\
---\end{array}$ & $\begin{array}{c}-- \\
--- \\
--- \\
--- \\
--\end{array}$ & $\begin{array}{c}--- \\
--- \\
--- \\
---\end{array}$ & $\begin{array}{c}--- \\
--- \\
--- \\
--- \\
---\end{array}$ & $\begin{array}{c}--- \\
--- \\
--- \\
--- \\
--\end{array}$ & $\begin{array}{c}--- \\
--- \\
--- \\
---\end{array}$ & $\begin{array}{l}--- \\
-- \\
-- \\
--- \\
--\end{array}$ & $\begin{array}{l}--- \\
--- \\
-- \\
--- \\
--\end{array}$ & $\begin{array}{r}98 \\
125 \\
107 \\
97 \\
91\end{array}$ & $\begin{array}{l}62 \\
62 \\
61 \\
61 \\
61\end{array}$ \\
\hline $\begin{array}{r}6 \\
7 \\
8 \\
9 \\
10\end{array}$ & $\begin{array}{c}--- \\
--- \\
--- \\
---\end{array}$ & $\begin{array}{c}--- \\
--- \\
--- \\
--- \\
--\end{array}$ & $\begin{array}{c}--- \\
--- \\
--- \\
--- \\
--\end{array}$ & $\begin{array}{c}-- \\
--- \\
--- \\
--- \\
--\end{array}$ & $\begin{array}{l}--- \\
--- \\
--- \\
---\end{array}$ & $\begin{array}{c}--- \\
--- \\
--- \\
---\end{array}$ & $\begin{array}{c}--- \\
--- \\
--- \\
---\end{array}$ & $\begin{array}{c}--- \\
--- \\
--- \\
--- \\
--\end{array}$ & $\begin{array}{l}--- \\
--- \\
--- \\
---\end{array}$ & $\begin{array}{c}--- \\
--- \\
--- \\
---\end{array}$ & $\begin{array}{l}85 \\
81 \\
77 \\
75 \\
74\end{array}$ & $\begin{array}{l}60 \\
60 \\
60 \\
60 \\
60\end{array}$ \\
\hline $\begin{array}{l}11 \\
12 \\
13 \\
14 \\
15\end{array}$ & $\begin{array}{c}-- \\
--- \\
--- \\
---\end{array}$ & $\begin{array}{l}--- \\
-- \\
--- \\
---\end{array}$ & $\begin{array}{c}--- \\
--- \\
--- \\
--- \\
--\end{array}$ & $\begin{array}{c}--- \\
--- \\
--- \\
--- \\
---\end{array}$ & $\begin{array}{c}--- \\
--- \\
--- \\
---\end{array}$ & $\begin{array}{c}--- \\
--- \\
--- \\
---\end{array}$ & $\begin{array}{c}--- \\
--- \\
--- \\
---\end{array}$ & $\begin{array}{c}--- \\
--- \\
--- \\
--- \\
--\end{array}$ & $\begin{array}{l}--- \\
--- \\
--- \\
--- \\
--\end{array}$ & $\begin{array}{l}--- \\
--- \\
--- \\
--- \\
---\end{array}$ & $\begin{array}{l}72 \\
71 \\
73 \\
73 \\
72\end{array}$ & $\begin{array}{l}60 \\
60 \\
60 \\
60 \\
61\end{array}$ \\
\hline $\begin{array}{l}16 \\
17 \\
18 \\
19 \\
20\end{array}$ & $\begin{array}{c}--- \\
--- \\
--- \\
---\end{array}$ & $\begin{array}{l}--- \\
-- \\
--- \\
---\end{array}$ & $\begin{array}{c}--- \\
--- \\
--- \\
---\end{array}$ & $\begin{array}{c}-- \\
--- \\
--- \\
---\end{array}$ & $\begin{array}{c}--- \\
--- \\
--- \\
---\end{array}$ & $\begin{array}{c}--- \\
--- \\
--- \\
---\end{array}$ & $\begin{array}{c}--- \\
--- \\
--- \\
---\end{array}$ & $\begin{array}{c}--- \\
--- \\
--- \\
---\end{array}$ & $\begin{array}{c}--- \\
--- \\
--- \\
--- \\
--\end{array}$ & $\begin{array}{l}--- \\
--- \\
--- \\
---\end{array}$ & $\begin{array}{l}71 \\
71 \\
70 \\
68 \\
67\end{array}$ & $\begin{array}{l}61 \\
60 \\
60 \\
61 \\
64\end{array}$ \\
\hline $\begin{array}{l}21 \\
22 \\
23 \\
24 \\
25\end{array}$ & $\begin{array}{l}-- \\
--- \\
--- \\
---\end{array}$ & $\begin{array}{l}--- \\
--- \\
--- \\
---\end{array}$ & $\begin{array}{c}--- \\
--- \\
--- \\
--- \\
--\end{array}$ & $\begin{array}{c}--- \\
--- \\
--- \\
---\end{array}$ & $\begin{array}{c}--- \\
--- \\
--- \\
---\end{array}$ & $\begin{array}{c}--- \\
--- \\
--- \\
---\end{array}$ & $\begin{array}{c}--- \\
--- \\
--- \\
--- \\
--\end{array}$ & $\begin{array}{c}--- \\
--- \\
--- \\
---\end{array}$ & $\begin{array}{l}--- \\
--- \\
-- \\
--- \\
--\end{array}$ & $\begin{array}{l}--- \\
--- \\
--- \\
--- \\
--\end{array}$ & $\begin{array}{l}68 \\
71 \\
71 \\
69 \\
68\end{array}$ & $\begin{array}{l}66 \\
66 \\
64 \\
67 \\
66\end{array}$ \\
\hline $\begin{array}{l}26 \\
27 \\
28 \\
29 \\
30 \\
31\end{array}$ & $\begin{array}{c}--- \\
--- \\
--- \\
--- \\
---\end{array}$ & $\begin{array}{l}--- \\
-- \\
--- \\
--- \\
---\end{array}$ & $\begin{array}{c}--- \\
--- \\
--- \\
--- \\
---\end{array}$ & $\begin{array}{c}--- \\
--- \\
--- \\
--- \\
---\end{array}$ & $\begin{array}{c}--- \\
--- \\
--- \\
--- \\
---\end{array}$ & $\begin{array}{c}--- \\
--- \\
---- \\
--- \\
---\end{array}$ & $\begin{array}{c}--- \\
--- \\
--- \\
--- \\
---\end{array}$ & $\begin{array}{c}--- \\
--- \\
--- \\
--- \\
---\end{array}$ & $\begin{array}{c}--- \\
--- \\
--- \\
--- \\
---\end{array}$ & $\begin{array}{l}--- \\
--- \\
--- \\
--- \\
---\end{array}$ & $\begin{array}{l}67 \\
66 \\
65 \\
64 \\
63 \\
63\end{array}$ & $\begin{array}{l}65 \\
67 \\
66 \\
65 \\
65 \\
---\end{array}$ \\
\hline
\end{tabular}

DISCHARGE, CUBIC FEET PER SECOND, WATER YEAR OCTOBER 2002 TO SEPTEMBER 2003 DAILY MEAN VALUES

\begin{tabular}{|c|c|c|c|c|c|c|c|c|c|c|c|c|}
\hline DAY & OCT & NOV & DEC & JAN & FEB & MAR & APR & MAY & JUN & JUL & AUG & SEP \\
\hline 1 & 75 & 87 & 82 & e72 & e 58 & e56 & 182 & e94 & e100 & e70 & e107 & 60 \\
\hline 2 & 81 & 88 & 104 & e67 & $\mathrm{e} 58$ & e 56 & $\begin{array}{l}169 \\
\text {. }\end{array}$ & e86 & e95 & e65 & $\mathrm{e} 103$ & 59 \\
\hline 3 & 74 & 87 & 97 & e64 & e 58 & e 56 & 154 & e 80 & e82 & e60 & e102 & 58 \\
\hline 4 & 80 & 87 & 96 & e64 & e 58 & e56 & 136 & e76 & e70 & $\mathrm{e} 55$ & e121 & 58 \\
\hline 5 & 108 & 87 & 93 & e64 & e58 & e56 & e135 & e72 & e60 & $\mathrm{e} 52$ & e108 & 57 \\
\hline 6 & 122 & 88 & 87 & e64 & e57 & e 56 & e120 & e70 & e52 & $\mathrm{e} 50$ & e97 & 57 \\
\hline 7 & 129 & 88 & 83 & e64 & e57 & e 56 & $\mathrm{e} 120$ & 65 & $\mathrm{e} 50$ & $\mathrm{e} 48$ & e90 & 56 \\
\hline 8 & 123 & 87 & 82 & e62 & e 57 & e56 & 112 & 62 & e52 & $\mathrm{e} 45$ & e86 & 56 \\
\hline 9 & 125 & 87 & e80 & e62 & e57 & e 56 & 110 & 59 & e55 & $\mathrm{e} 44$ & 83 & 56 \\
\hline 10 & 116 & 91 & e80 & e62 & e 57 & e 56 & 114 & 58 & e60 & e 46 & 80 & 55 \\
\hline 11 & 107 & 102 & 81 & e62 & e57 & e56 & 139 & 59 & e70 & e55 & 76 & 55 \\
\hline 12 & 104 & 102 & 80 & e62 & e 57 & e56 & 183 & e90 & e130 & e65 & 73 & 55 \\
\hline 13 & 118 & 99 & 79 & e62 & e57 & e 56 & 203 & e150 & $\mathrm{e} 120$ & $\mathrm{e} 70$ & 70 & 56 \\
\hline 14 & 116 & 99 & 79 & e62 & e 57 & e 56 & 213 & $\mathrm{e} 140$ & e115 & e60 & 69 & 68 \\
\hline 15 & 108 & 97 & 78 & e62 & e57 & e58 & 281 & e130 & e100 & e52 & 69 & 90 \\
\hline 16 & 101 & 90 & 76 & e60 & e56 & e 58 & 313 & e120 & e90 & e 48 & 68 & 96 \\
\hline 17 & 96 & 95 & e76 & e60 & e56 & e60 & 296 & e115 & e 80 & $\mathrm{e} 45$ & 67 & 91 \\
\hline 18 & 93 & 89 & 80 & e60 & e56 & e60 & 280 & $\mathrm{e} 100$ & e70 & $\mathrm{e} 40$ & 66 & 85 \\
\hline 19 & 93 & 90 & 86 & e60 & e56 & e65 & 257 & e90 & e65 & e36 & 65 & 80 \\
\hline 20 & 93 & 90 & 90 & e60 & e56 & e65 & 340 & e80 & e60 & e34 & 64 & 76 \\
\hline 21 & 93 & 88 & 89 & $\mathrm{e} 58$ & e 56 & e70 & 401 & $\mathrm{e} 75$ & e58 & e60 & 63 & 72 \\
\hline 22 & 94 & 88 & 87 & e 58 & e 56 & e80 & e 380 & e72 & e58 & e337 & 62 & 76 \\
\hline 23 & 93 & 87 & 86 & e 58 & e 56 & e90 & $\mathrm{e} 320$ & $\mathrm{e} 70$ & e55 & e 234 & 61 & 90 \\
\hline 24 & 92 & 86 & 86 & e 58 & e 56 & e100 & e250 & e68 & e55 & e191 & 61 & 86 \\
\hline 25 & 90 & 86 & 86 & e 58 & e56 & $\mathrm{e} 120$ & $\mathrm{e} 200$ & e64 & e55 & e176 & 61 & 89 \\
\hline 26 & 89 & 85 & 84 & e58 & e56 & e145 & e160 & e60 & e55 & e159 & 62 & 99 \\
\hline 27 & 89 & 84 & 80 & e 58 & e 56 & 144 & $\mathrm{e} 140$ & e56 & e55 & e148 & 61 & 135 \\
\hline 28 & 90 & 83 & 83 & e 58 & e 56 & 174 & $\mathrm{e} 120$ & $\mathrm{e} 56$ & e60 & e134 & 62 & 126 \\
\hline 29 & 89 & 84 & 80 & e 58 & -- & 198 & $\mathrm{e} 110$ & $\mathrm{e} 58$ & e62 & $\mathrm{e} 123$ & 64 & 120 \\
\hline 30 & 87 & 84 & 79 & e 58 & --- & 216 & $\mathrm{e} 100$ & e60 & e68 & e115 & 62 & 113 \\
\hline 31 & 86 & - & 78 & e58 & --- & 239 & --- & e65 & --. & e109 & 61 & - \\
\hline
\end{tabular}

(e) Estimated. 


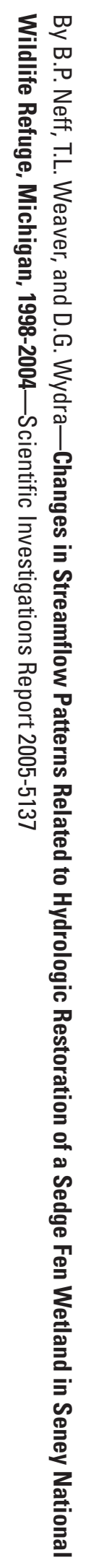

8 Printed on recycled paper 